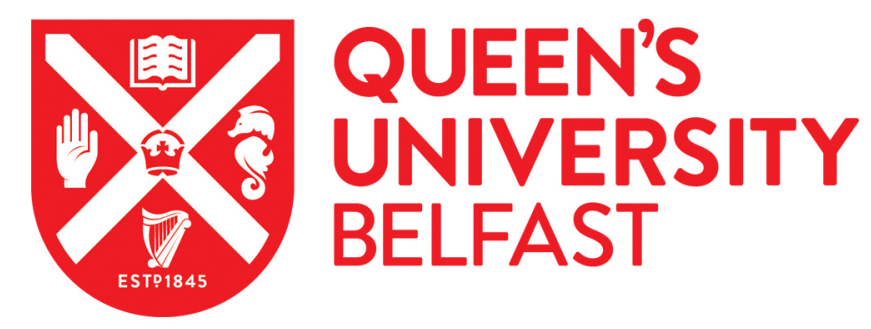

\title{
Use of Vietnamese rice husk ash for the production of sodium silicate as the activator for alkali-activated binders
}

Tong, K. T., Vinai, R., \& Soutsos, M. N. (2018). Use of Vietnamese rice husk ash for the production of sodium silicate as the activator for alkali-activated binders. Journal of Cleaner Production, 201, 272-286.

Published in:

Journal of Cleaner Production

Document Version:

Peer reviewed version

Queen's University Belfast - Research Portal:

Link to publication record in Queen's University Belfast Research Portal

Publisher rights

(C) 2018 Elsevier Ltd. All rights reserved.

This manuscript version is made available under the CC-BY-NC-ND 4.0 license http://creativecommons.org/licenses/by-nc-nd/4.0/,which permits distribution and reproduction for noncommercial purposes, provided the author and source are cited.

\section{General rights}

Copyright for the publications made accessible via the Queen's University Belfast Research Portal is retained by the author(s) and / or other copyright owners and it is a condition of accessing these publications that users recognise and abide by the legal requirements associated with these rights.

Take down policy

The Research Portal is Queen's institutional repository that provides access to Queen's research output. Every effort has been made to ensure that content in the Research Portal does not infringe any person's rights, or applicable UK laws. If you discover content in the Research Portal that you believe breaches copyright or violates any law, please contact openaccess@qub.ac.uk. 


\title{
Use of Vietnamese rice husk ash for the production of sodium silicate as the activator for alkali-activated binders
}

Kien T. Tong ${ }^{1,2}$, Raffaele Vinai ${ }^{2,3,{ }^{*},}$ Marios N. Soutsos ${ }^{2}$

\author{
${ }^{1}$ National University of Civil Engineering, Faculty of Building Materials, 55 Giai Phong, Hanoi, \\ Vietnam; Email: kientt@nuce.edu.vn \\ 2 School of Natural and Built Environment, Queen’s University Belfast, David Keir Building, 39 \\ Stranmillis Road, Belfast BT9 5AG, United Kingdom; Email: m.soutsos@qub.ac.uk \\ ${ }^{3}$ College of Engineering, Mathematics and Physical Science, University of Exeter, North Park Road, \\ Exeter EX4 4QF, United Kingdom; Email: r.vinai@exeter.ac.uk \\ ${ }^{*}$ Corresponding author. Telephone +44 (0) 1392723627
}

\begin{abstract}
Geopolymer and Alkali-Activated Binders (AAB) has recently emerged as a new, green material with the potential to replace Portland cement in several applications. They can reduce the $\mathrm{CO}_{2}$ footprint of concrete by up to $80 \%$ and this is in addition to being more durable in certain aggressive environments. However, commercial alkaline activators contribute significantly to the cost and $\mathrm{CO}_{2}$ footprint of $\mathrm{AAB}$ concrete mixes. This research investigated the production of a low cost, low environmental impact sodium silicate solution (waterglass) from Rice Husk Ash (RHA) and more specifically RHA from Vietnam. A hydrothermal process for the dissolution of RHA in sodium hydroxide solution was developed. Sodium hydroxide solution concentration, process temperature and duration were studied. Optimised procedure parameters were found to be: $\mathrm{NaOH}$ concentration $3 \mathrm{M}$, heating temperature $80^{\circ} \mathrm{C}$ and heating duration 3h. The obtained solution was used for the production of AAB mortar made with a blend of fly ash and ground granulated blast furnace slag. Obtained compressive strength of mortar was in the range of $60 \mathrm{MPa}$ at 28 days, matching the strength obtained from control samples produced with commercially available activators. Microstructural investigation (isothermal calorimetry, infrared spectroscopy, X-ray diffraction and thermogravimetric analysis) on pastes confirmed the equivalence between the solution produced with the optimised method and commercially available options. Cost analysis indicated that the proposed method could allow a reduction of almost 55\% of the cost for the activation of AAB. Results from a simplified preliminary environmental analysis suggested increased sustainability of the RHA-derived solution when compared with commercially available waterglass.
\end{abstract}

Keywords: Alkali-activated binder, Alkaline activators, Rice Husk Ash, Fly Ash, Ground Granulated Blast Furnace Slag, simplified environmental analysis. 


\section{INTRODUCTION}

\subsection{Background}

Concrete is one of the most common building materials used in the construction of buildings, bridges and infrastructure across the world. However, the production of Portland Cement (PC) has already been recognised as a cause of significant environmental threats as it is responsible for $8 \%$ of anthropogenic $\mathrm{CO}_{2}$ emissions worldwide (Mehta, 2002; Olivier et al., 2015; Provis, 2014). In order to reduce the $\mathrm{CO}_{2}$ emissions, geopolymers or alkali-activated binders (AAB) are considered to offer an alternative to PC for concrete production. These concretes offer a number of benefits over conventional PC concrete including significantly lower $\mathrm{CO}_{2}$ emissions (up to 80\%) than PC concrete (Davidovits, 2002). Alkaliactivated slag concrete has 73\% lower greenhouse gas emissions (Davidovits, 1994), 43\% less energy consumption and uses 25\% less water than conventional Portland cement concrete (Jiang et al., 2014). Additional benefits include (a) better thermal insulation properties; (b) higher fire resistance and (c) improved durability (Palomo et al., 1999; Roy, 1999; Schneider et al., 2011; Soutsos et al., 2015).

Alkali Activated Binders (AAB) are produced from an alumino-silicate source containing vitreous silica and alumina components, such as ground granulated blast furnace slag (GGBS), metakaolin, fly ash (FA). The precursor material is mixed with an alkaline activator, which promotes the dissolution of the silicate and aluminate species and their consequent polycondensation to form a binder with good mechanical performance (Shi et al., 2006; Duxson et al., 2007). Sodium silicate has been extensively used as an alkaline activator in $\mathrm{AAB}$ and geopolymer concrete. It generally results in the highest mechanical strength development along with a reduced permeability, which is associated with a stable and dense structure. However, the use of sodium silicate markedly increases the embodied energy and $\mathrm{CO}_{2}$ emissions associated with AABs, as a consequence of its manufacturing process. This typically involves the calcination of sodium carbonate $\left(\mathrm{Na}_{2} \mathrm{CO}_{3}\right)$ and quartz sand $\left(\mathrm{SiO}_{2}\right)$ at temperatures between 1400 and $1500{ }^{\circ} \mathrm{C}$ (Shi et al., 2006; Davidovits, 2011), generating $\mathrm{CO}_{2}$ from the decomposition of $\mathrm{Na}_{2} \mathrm{CO}_{3}$ and from the fuel used to reach these high temperatures (Fawer et al., 1999). The process is also expensive due to its energy consumption. The development of alternative activators with reduced $\mathrm{CO}_{2}$ footprint and thus better sustainability credentials when used for geopolymer concrete is therefore much desired and can lead to significant reduction in the global warming potential of alkali activated binders (Passuello et al., 2017; Torres-Carrasco et al., 2015; Torres-Carrasco and Puertas, 2015).

In 2016 the worldwide rice and paddy production was over 952 million tonnes (FAOSTAT, 2018). Rice husk is an agricultural waste material. The rice husk is the outer cover of the rice and on average it accounts for $20 \%$ of the paddy produced. Annual husk output is about 190 million tonnes. Rice husk has various applications in different industries, e.g. (a) as an industrial fuel for processing paddy and generation of process steam in power plants (1 tonne of rice husk is required for producing $1 \mathrm{MWh}$ of electricity); (b) as a fertilizer and substrate or pet food fibre; (c) as an ingredient for the preparation of 
activated carbon or substrate for silica and silicon compound production; and (d) as raw material for brick production (Kumar et al., 2013; Natarajan et al., 1998). The largest national rice producers (China, India, Thailand, Cambodia) use rice husk as a renewable energy resource for power generation from biomass (Kapur et al., 1996; Bhattacharyya, 2014). Vietnam generates approximately 8.7 million tonnes of rice husk per year as a by-product from rice milling (FAOSTAT, 2018).

Rice husk in Vietnam is currently burnt in simple incinerators for resident energy, industrial steam and thermal power plant. If all the rice husk was used for electricity generation, it would produce approximately 8.7 billion kWh of electricity and 1.7 million tonnes of rice husk ash (RHA) per year. This RHA is rich in silica (approximately 90\%), similarly to silica fume and glass, mostly in amorphous form (Van et al., 2013).

RHA has been extensively investigated as a potential source of silicates. Several processes have been described in the literature (Chandrasekhar et al., 2003; Foletto et al., 2006; Ma et al., 2012; Ghosh and Bhattacherjee, 2013; Sjahrul et al., 2013; Cui et al., 2015; Liu et al., 2016), but a complete review of these is outside the scope of this paper.

There exist only a relatively small number of studies on the utilisation of RHA as a precursor for the production of AAB. RHA was blended with other precursors such as fly ash (Detphan and Chindaprasirt, 2009; Hwang and Huynh, 2015; Ziegler et al., 2016), calcined water treatment sludge (Nimwinya et al., 2016), slag and palm oil fuel ash (Karim et al., 2013), slag and fly ash (Karim et al., 2015), slag (Suksiripattanapong et al., 2017), or red mud (He et al., 2013). Research results confirmed the reactivity of RHA in an alkaline environment as a Si donor.

More recently, RHA has been investigated as a silica source for the production of sodium silicates, which are typically used for the alkali activation of geopolymers and AAB. Research focussed mainly on the use of RHA-based silicate solutions for the activation of metakaolin, either neat metakaolin (Kamseu et al., 2017; Tchakouté et al., 2016a, 2016b) or metakaolin blended with other precursors such as slag (Bernal et al, 2012), water treatment sludge (Geraldo et al., 2017), or fly ash (Mejía et al., 2016). Only few publications investigated the use of RHA-based sodium silicate solutions for the alkaline activation of other precursors, such as fluid catalytic cracking catalyst (Bouzón et al., 2014), slag (Bernal et al, 2015), or fly ash/slag blends (Mejía et al., 2013). Details from the literature on RHA utilisation for the production of sodium silicates for activation of AAB are given in Table 1.

Results from the studies listed in Table 1 confirmed the general suitability of RHA as source of silicate for the production of silicate solutions. Compressive strengths were found to be influenced by the silicate content of the solutions and by the precursor used for producing the binder. Metakaolin-based AAB gave strengths comparable with the control mixes, whilst slag-based AABs gave higher strengths (Bernal et al., 2015). 
Table 1 Literature available on the utilisation of RHA for the production of silicate solutions for the activation of AAB.

\begin{tabular}{|c|c|c|c|}
\hline Reference & $\begin{array}{c}\text { AAB } \\
\text { precursor }\end{array}$ & $\begin{array}{l}\text { Extraction } \\
\text { technique }\end{array}$ & Process parameters \\
\hline Kamseu et al., 2017 & Metakaolin & $\begin{array}{l}\text { Dissolution in } \mathrm{NaOH} \\
\text { solution at room } \\
\text { temperature }\end{array}$ & $\begin{array}{l}\text { RHA ground to }<45 \mu \mathrm{m} \text { and dissolved in } \\
\mathrm{NaOH} \text { solution having different concentrations } \\
(8,10 \text { and } 12 \mathrm{M}) \text { for a minimum of } 24 \mathrm{~h} \text {. }\end{array}$ \\
\hline $\begin{array}{l}\text { Tchakouté et al., } \\
\text { 2016a }\end{array}$ & Metakaolin & $\begin{array}{l}\text { Dissolution in } \mathrm{NaOH} \\
\text { solution at } 80^{\circ} \mathrm{C}\end{array}$ & $\begin{array}{l}\text { Different ratios of solid } \mathrm{NaOH} \text { and RHA } \\
\text { powder mixed in } 200 \mathrm{ml} \text { of distilled water for } \\
2 \text { h at } 80{ }^{\circ} \mathrm{C} \text {. Obtained solutions stored at room } \\
\text { temperature for at least } 24 \mathrm{~h} \text { before use. }\end{array}$ \\
\hline $\begin{array}{l}\text { Tchakouté et al., } \\
\text { 2016b }\end{array}$ & Metakaolin & $\begin{array}{l}\text { Dissolution in } \mathrm{NaOH} \\
\text { solution at } 100^{\circ} \mathrm{C}\end{array}$ & $\begin{array}{l}\mathrm{NaOH} \text { pellets and RHA powder mixed with a } \\
200 \mathrm{ml} \text { of distilled water for } 2 \mathrm{~h} \text { at } 100^{\circ} \mathrm{C} \text {. } \\
\text { Obtained solutions stored at room temperature } \\
\text { for at least } 7 \text { days before use. }\end{array}$ \\
\hline Bernal et al., 2012 & $\begin{array}{l}\text { Metakaolin/ } \\
\text { slag blends }\end{array}$ & $\begin{array}{l}\text { Dissolution in } \mathrm{NaOH} \\
\text { solution at room } \\
\text { temperature }\end{array}$ & $\begin{array}{l}\text { RHA particle size distribution between } 1 \text { and } \\
60 \mu \text { mith a d } d_{50} \text { of } 9.2 \mu \text { m. RHA and aqueous } \\
\text { solution of } \mathrm{NaOH} \text { mixed for } 10 \mathrm{~min} \text {, then kept } \\
\text { at } 25^{\circ} \mathrm{C} \text { for } 24 \mathrm{~h} \text { before use. }\end{array}$ \\
\hline Geraldo et al., 2017 & $\begin{array}{l}\text { Metakaolin/ } \\
\text { water } \\
\text { treatment } \\
\text { sludge }\end{array}$ & $\begin{array}{l}\text { Dissolution in } \mathrm{NaOH} \\
\text { solution at } 90{ }^{\circ} \mathrm{C}\end{array}$ & $\begin{array}{l}\text { RHA and aqueous solution of } \mathrm{NaOH} \text { mixed for } \\
30 \text { min at } 90{ }^{\circ} \mathrm{C} \pm 5^{\circ} \mathrm{C} \text {, then stored at room } \\
\text { temperature before use. }\end{array}$ \\
\hline Mejía et al., 2016 & $\begin{array}{l}\text { Metakaolin/ } \\
\text { fly ash }\end{array}$ & $\begin{array}{l}\text { Dissolution in } \mathrm{NaOH} \\
\text { solution at room } \\
\text { temperature }\end{array}$ & $\begin{array}{l}\text { RHA ground to particle size of } 5 \mu \mathrm{m} \text {. } \\
\text { Dissolved in } \mathrm{NaOH} \text { solution under stirring for } \\
24 \mathrm{~h} \text { at room temperature. }\end{array}$ \\
\hline Bouzón et al., 2014 & $\begin{array}{l}\text { fluid } \\
\text { catalytic } \\
\text { cracking } \\
\text { catalyst }\end{array}$ & $\begin{array}{l}\text { Dissolution in } \mathrm{NaOH} \\
\text { solution at boiling } \\
\text { temperature with } \\
\text { reflux }\end{array}$ & $\begin{array}{l}\text { RHA ground to particle size of } 20.3 \mu \mathrm{m} .3 \mathrm{~g} \text { of } \\
\mathrm{NaOH} \text { and } 2.9 \mathrm{~g} \text { of RHA dissolved in } 10 \mathrm{ml} \text { of } \\
\text { deionised water, which was boiled in a reflux } \\
\text { system for different times ( } 5-240 \mathrm{~min}) \text {. }\end{array}$ \\
\hline Bernal et al., 2015 & Slag & $\begin{array}{l}\text { Dissolution in } \mathrm{NaOH} \\
\text { solution at room } \\
\text { temperature }\end{array}$ & $\begin{array}{l}\text { Particle size distribution between } 1 \text { and } 60 \mu \mathrm{m} \\
\text { with a } \mathrm{d}_{50} \text { of } 9.2 \mu \mathrm{m} \text {. RHA and aqueous } \\
\text { solution of } \mathrm{NaOH} \text { mixed for } 10 \mathrm{~min} \text {, then kept } \\
\text { at } 25 \mathrm{C} \text { for } 24 \mathrm{~h} \text { before use. }\end{array}$ \\
\hline Mejía et al., 2013 & fly ash/slag & $\begin{array}{l}\text { Dissolution in } \mathrm{NaOH} \\
\text { solution at room } \\
\text { temperature }\end{array}$ & $\begin{array}{l}\text { Particle size distribution with } \mathrm{d}_{50} \text { of } 36.9 \text { - } 39.5 \\
\mu \mathrm{m} \text {. RHA and aqueous solution of } \mathrm{NaOH} \text { kept } \\
\text { at room temperature for } 24 \mathrm{~h} \text { before use. }\end{array}$ \\
\hline
\end{tabular}

\subsection{Research Significance}

The dissolution of RHA in $\mathrm{NaOH}$ solution, which is a hydrothermal method, is a well-known extraction technique. However, its use for the production of sodium silicate which in turn is to be used for the activation of $\mathrm{AAB}$ requires further research in that:

- Mejía et al. (2013) presented results on the complete substitution of commercial sodium silicate with RHA-based solution for the activation of 100\% fly ash, 100\% slag and blended (50/50) fly ash/slag -based AABs. Compressive strengths lower than the control mixes were obtained. It was suggested that this was because of the presence of crystalline $\mathrm{SiO}_{2}$ in RHA and therefore reduced availability of silicates for the polymerisation reaction. However, the microstructural analysis was carried out only on samples produced with RHA with a low amorphous content, whereas the strength reduction was also observed on samples prepared with almost fully 
amorphous RHA. The use of RHA-based sodium silicate solutions for the activation of fly ash/slag blended binders requires therefore further investigation.

- Parameters influencing the efficiency of the hydrothermal method have been investigated but the optimum conditions for RHA dissolution (i.e., process temperature and duration, $\mathrm{NaOH}$ solution concentration) have not yet been confirmed, see Table 1. Further studies are therefore required.

- $\quad$ RHA can offer an alternative to the commercial solution with the potential advantage of lower cost and lower environmental impact, as has been suggested in the literature (Passuello et al., 2017; Torres-Carrasco et al., 2015; Torres-Carrasco and Puertas, 2015). Some further economic and environmental analysis, even at a preliminary level, would strengthen the case for converting a waste into an added value product for either local use or for export to provide a valuable income stream.

This paper presents findings from an investigation aimed at optimising the hydrothermal process for the production of RHA-based silicate solution. Parameters such as the concentration of the sodium hydroxide solution, process temperature and duration were investigated for minimizing energy consumption and low carbon footprint. Figure 1 shows the comparison between close vessel process for sodium silicate production and the proposed method for the production of RHA-based silicate solution. The obtained RHA-based sodium silicates were used in conjunction with $\mathrm{NaOH}$ solution for activating a blend of $60 \%$ fly ash and $40 \%$ GGBS. Mortar samples were used for compressive strength measurements and these were compared with a control mix with commercially available sodium silicate.Paste samples were used for microstructural characterisation,. The aim was to compare the efficiency of the RHA-derived silicate solution to commercially available waterglass. A preliminary cost analysis was carried out for assessing the economic sustainability of the process. A simplified environmental analysis was also carried out for assessing the benefits in terms of environmental impact of the proposed RHA-based sodium silicate when compared with commercially available option. 
a) Autoclave reactor

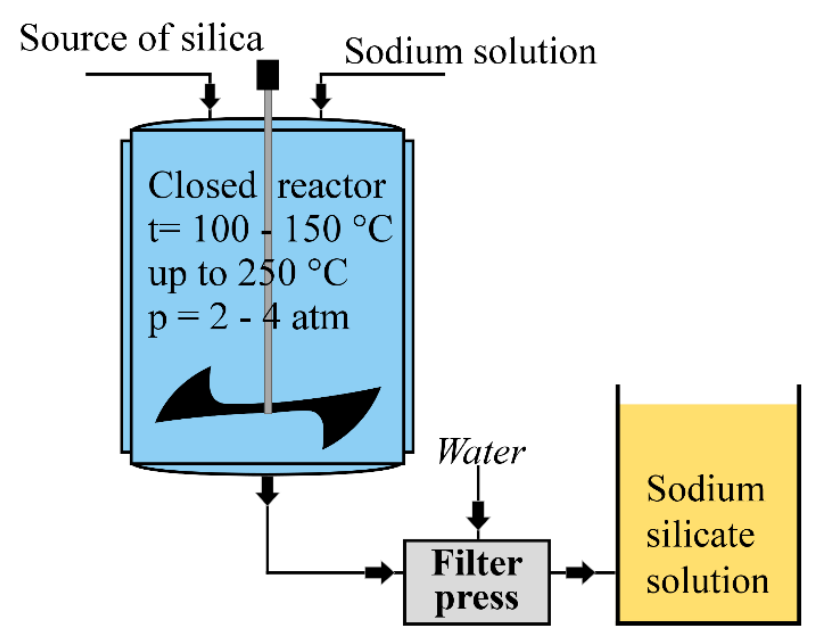

\section{b) Proposed process}

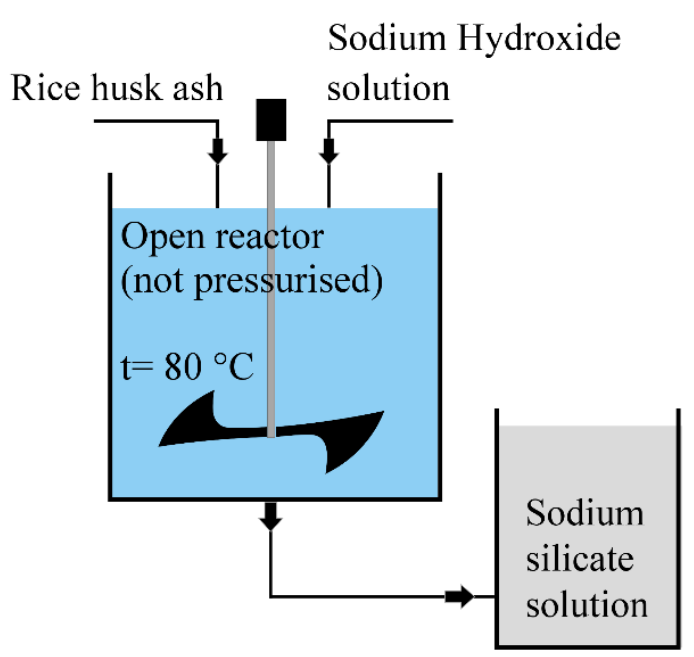

Figure 1 Comparison between (a) close vessel process for sodium silicate; (b) proposed method for the production of RHA-based sodium silicate solution.

\section{MATERIALS AND EXPERIMENTAL PROCEDURES}

\subsection{Rice Husk Ash (RHA)}

The RHA used in this study was obtained by burning rice husk in a modified incinerator available at the National University of Civil Engineering (Hanoi, Vietnam), see Figure 2. The working principle of the incinerator replicates the equipment developed by Shuichi Sugita (Sugita, 1994; Van, 2013). The method consists of carbonisation at about $300-400{ }^{\circ} \mathrm{C}$ and incineration at about $600-800{ }^{\circ} \mathrm{C}$. The duration of the process depends on the mass of processed rice husk, ranging from 10 hours for about $800 \mathrm{~g}$ of rice husk to about 72 hours when a mass of $500 \mathrm{~kg}$ of rice husk is to be processed (Sugita, 1994). Times and temperatures are intended for maximising the amorphous content of the RHA, as higer temperature and shorter times would induce the formation of crystalline $\mathrm{SiO}_{2}$ (Fernandes et al., 2017; Ananthi et al., 2016; Bhattacharyya, 2014; Chandrasekhar et al., 2003; Bui, 2001). Amorphous RHA with a SiO2 content $>95 \%$ is available on the market and therefore the industrial upscale of the proposed sodium silicate production method is possible. 

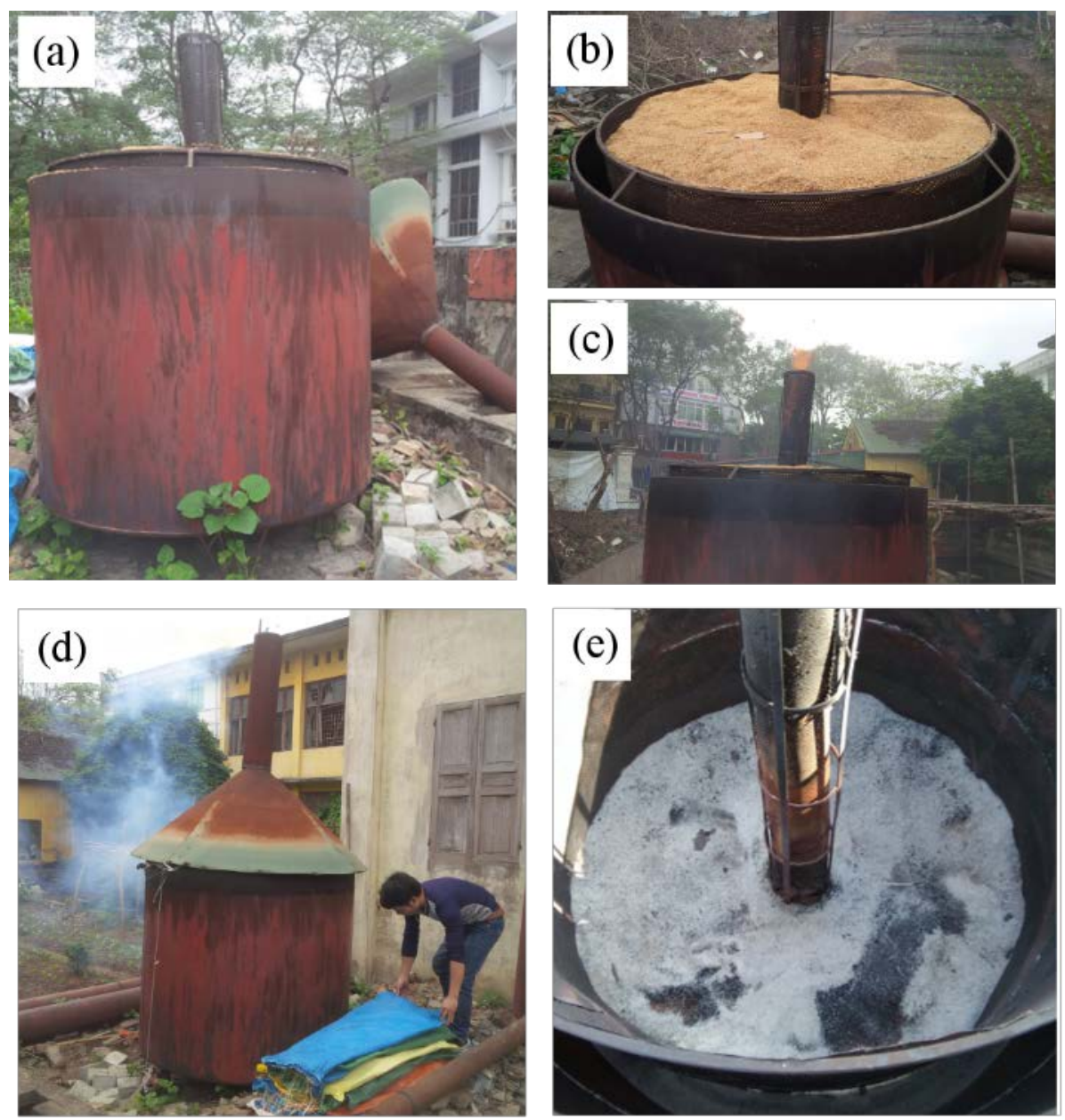

Figure 2 Incinerator used for the production of RHA and sequence of operations. (a) The incinerator cap is removed; (b) the rice husk is loaded into the incinerator; (c) ignition is started in the central chimney with combustible material such as paper; (d) the incinerator cap is put in place and the combustion runs at the required pace; (e) at the end of the process, RHA is obtained (white material: amorphous RHA, black material: carbonised RHA).

The RHA was then ground at 300 rpm in a laboratory ball mill Retsch PM400 for achieving a mean particle size $\left(\mathrm{d}_{50}\right)$ between 5 and $10 \mu \mathrm{m}$, as per literature suggestions (see Table 1 ). The rationale behind this choice was that the finer the RHA powder, the higher the specific area is, benefitting the reaction kinetics. Particle size distributions of ground RHA were determined with a laser diffraction particle size analyser and are shown in Figure 3. Milling times of 15 and 30 minutes were sufficient for achieving the desired fineness. The actual values of mean particle diameter $\left(\mathrm{d}_{50}\right)$ obtained after grinding for 15 and 30 minutes were 6.82 and $6.02 \mu \mathrm{m}$ respectively, whereas initial $\mathrm{d}_{50}$ (i.e., before milling) was $95.87 \mu \mathrm{m}$. The specific surface areas were determined by BET nitrogen absorption method, and the results were 30.0 and $29.0 \mathrm{~m}^{2} / \mathrm{g}$ for 15 and $30 \mathrm{~min}$ milling time respectively. Results showed that 15 minutes of grinding were sufficient and further grinding did not significantly increase the specific surface area nor 
the fineness of the powder. RHA samples ground for 15 min were therefore used for the subsequent experiments.

The obtained RHA had high silica content, as the sample had more than $90 \%$ of $\mathrm{SiO}_{2}$ and low carbon content, see Table 2 (minor oxides are not included). X-ray diffraction (XRD) analysis (Figure 4) showed that the investigated RHA mainly consisted of a large quantity of amorphous phases and minor presence of crystalline $\mathrm{SiO}_{2}$, presumably formed during the incineration phase at temperatures in the range $600-800^{\circ} \mathrm{C}$. The amorphous content was not determined with analytical analysis, but the diffused halo observed in the diffractogram between $15^{\circ}$ and $30^{\circ} 2 \theta$ suggested that almost all the sample was amorphous, as commonly found in the literature.

The amorphous content depends on the incineration process parameters. A lower amorphous content would adversely affect the RHA dissolution, as the crystalline structure of $\mathrm{SiO}_{2}$ would be more difficult to break under the hydrothermal conditions. The degree of crystallinity of RHA is a limiting factor that could significantly affect the process parameters.

Table 2 Chemical compositions of FA, GGBS and RHA

\begin{tabular}{|c|c|c|c|c|c|c|c|c|c|c|}
\hline $\begin{array}{c}\text { Chemical } \\
\text { composition }\end{array}$ & $\mathrm{CaO}$ & $\mathrm{SiO}_{2}$ & $\mathrm{Al}_{2} \mathrm{O}_{3}$ & $\mathrm{MgO}$ & $\mathrm{SO}_{3}$ & $\mathrm{~K}_{2} \mathrm{O}$ & $\mathrm{TiO}_{2}$ & $\mathrm{Fe}_{2} \mathrm{O}_{3}$ & $\mathrm{Na}_{2} \mathrm{O}$ & L.O.I \\
\hline RHA & 0.9 & 90.5 & 0.3 & 0.4 & 0.4 & 2.0 & - & 0.2 & 0.1 & 3.8 \\
\hline FA & 2.2 & 46.8 & 22.5 & 1.3 & 0.9 & 4.1 & 1.1 & 9.2 & 0.9 & 3.6 \\
\hline GGBS & 43.7 & 29.4 & 11.2 & 6.9 & 1.8 & 0.9 & 0.7 & 0.4 & 1.0 & 2.4 \\
\hline
\end{tabular}

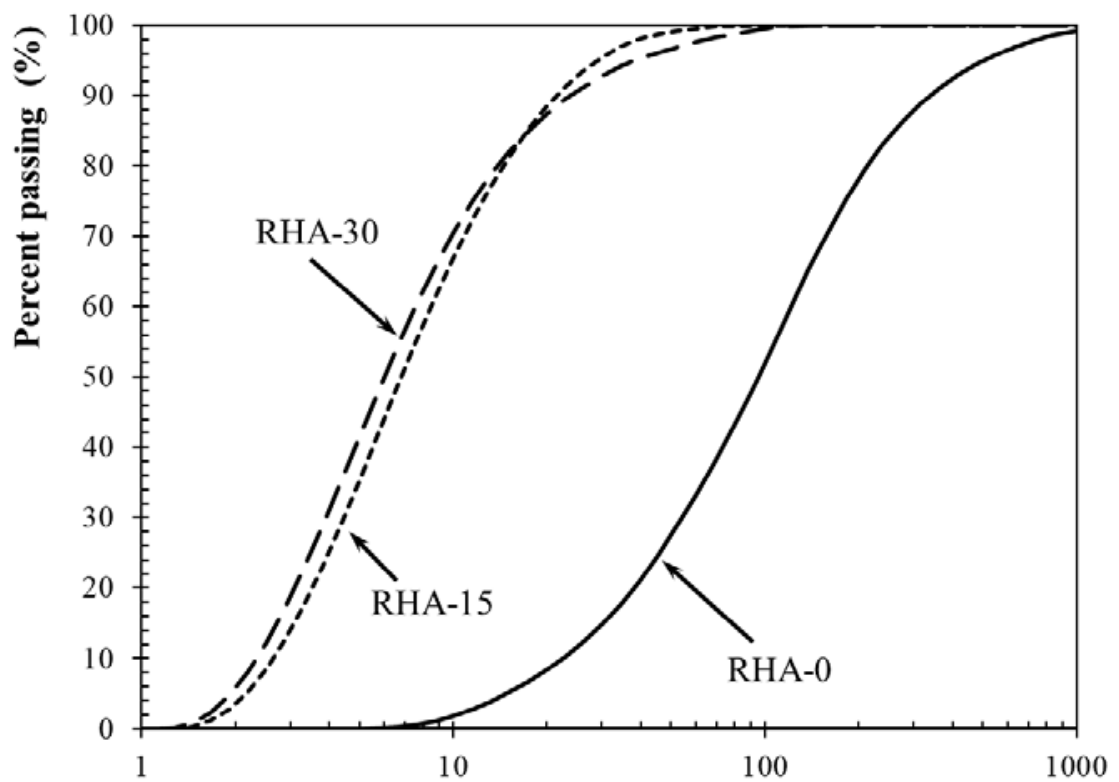

Grain size $(\mu \mathrm{m})$

Figure 3 Particle size distributions of RHA before (RHA-0) and after (RHA-15 and RHA-30) grinding. Numbers indicate the grinding times in minutes. 


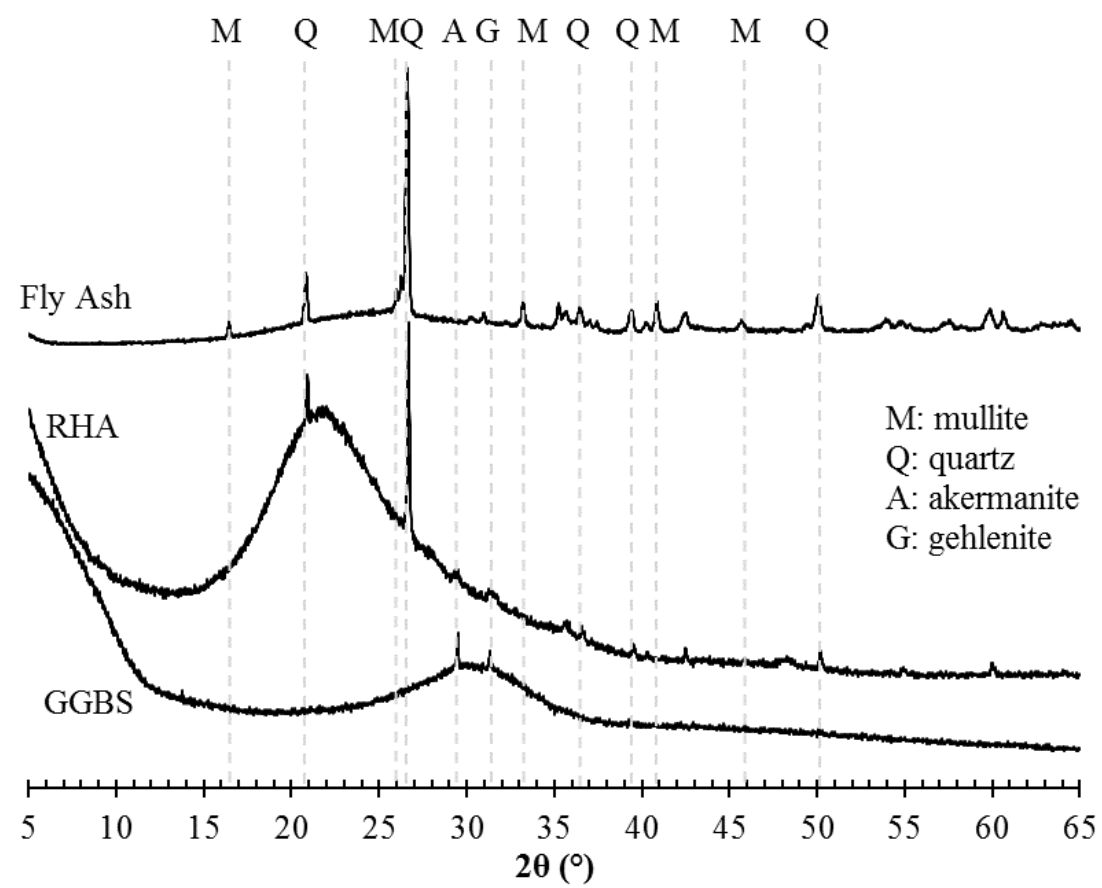

Figure 4 XRD patterns of RHA, FA and GGBS

\subsection{Production of sodium silicate solution from RHA}

Sodium silicate solution was produced by a hydrothermal method, dissolving RHA powder into $\mathrm{NaOH}$ solution heated and kept under magnetic stirring. The well-known factors influencing the hydrothermal process were investigated in the following ranges:

- Heating temperature: 5 temperatures (room temperature, 60, 80, 90 and $100{ }^{\circ} \mathrm{C}$ ).

- Heating time: 5 durations (1, 3, 5, 7 and 15 hours of heating).

- $\mathrm{NaOH}$ concentration: 5 concentrations (1.0, 2.0, 3.2, 4.9, and $6.5 \mathrm{M})$ were used; obtained by dissolving increasing amount of $\mathrm{NaOH}$ in water.

The investigated ranges were based on the available information in the literature as shown in Table 1. The efficiency of the dissolution process was evaluated by assessing the percentage of dissolved $\mathrm{SiO}_{2}$ compared to the estimated quantity initially available in the RHA. This indicator was expressed as a mass ratio of dissolved $\mathrm{SiO}_{2}$ over the total $\mathrm{SiO}_{2}$ available from RHA. The dissolved $\mathrm{SiO}_{2}$ was determined according to the Vietnamese standard 64TCN 38: 1986, which involves the following steps:

- The RHA sludge resulting from the hydrothermal process was filtered and thoroughly washed with a 50/50 mixture of distilled water and ethanol.

- The obtained clear solution was neutralised with $\mathrm{HCl}$ solution $1 \%$ conc.

- $\quad$ The precipitate (i.e. pure $\mathrm{SiO}_{2}$ ) was filtered and washed on a filter paper. The precipitate was washed by deionized water several times and then both filter paper and precipitate were calcined in an oven at $500{ }^{\circ} \mathrm{C}$ for removing (dehydrate) all the chemically-bound water, until no mass change was observed (about 5 hours). 
- The mass of pure $\mathrm{SiO}_{2}$, dissolved from RHA, was weighted, and the yield of silica ratio was determined according to the following equation:

$$
\text { Yield of silica }=\frac{\text { weight of silica } \text { obtained }}{\text { weight of silica in } R H A} \times 100
$$

\subsection{Binder and commercial activators}

The binder used in this study was a mixture consisting of $60 \%$ class $\mathrm{F}$ fly ash (FA, supplied by Power Minerals Ltd., UK) and 40\% ground granulated blast furnace slag (GGBS, supplied by Civil and Marine Ltd., Hanson group, UK) by weight. Average particle sizes $\left(\mathrm{d}_{50}\right)$ were 16.8 and $14.4 \mu \mathrm{m}$ for FA and GGBS respectively, whilst particle densities were 2.42 and $2.92 \mathrm{~g} / \mathrm{cm}^{3}$ for FA and GGBS respectively. Chemical compositions of FA and GGBS were determined by XRF analysis and are shown in Table 2. The alkaline coefficients of the GGBS (Pal et al., 2003) were calculated as:

$$
\begin{aligned}
& K=\frac{\mathrm{CaO}+\mathrm{MgO}+\mathrm{Al}_{2} \mathrm{O}_{3}}{\mathrm{SiO}_{2}}=2.1 \\
& K_{b}=\frac{\mathrm{CaO}+\mathrm{MgO}}{\mathrm{SiO}_{2}+\mathrm{Al}_{2} \mathrm{O}_{3}}=1.25
\end{aligned}
$$

With $\mathrm{K}>1.4$ and $\mathrm{K}_{\mathrm{b}}>1.0$, the slag can be classified as neutral slag with good hydraulic properties (Pal et al., 2003). The total $\mathrm{SiO}_{2}+\mathrm{Al}_{2} \mathrm{O}_{3}+\mathrm{Fe}_{2} \mathrm{O}_{3}$ content in $\mathrm{FA}$ was $78.5 \%$, higher than the minimum of 70\% required for Class F according to ASTM C618 (2008). Mineralogical compositions of FA and GGBS were determined with XRD analysis, indicating that the main crystalline phases for FA were quartz and mullite, whilst the amorphous content was 86\%, whereas GGBS was almost entirely in amorphous state, with minor presence of akermanite and gehlenite. Results are shown in Figure 4.

The analysis of the effect of variation of chemical composition of FA, GGBS and RHA was outside the scope of this study. No major deviations from the obtained results would be expected when materials with similar properties (i.e. class F fly ash and neutral slag) are used. Previous works suggested that the reactivity of FA is influenced mainly by average grain size, amorphous content and loss on ignition (Soutsos et al., 2016).

Sodium hydroxide used in this study was a commercial grade of $99 \%$ purity. $\mathrm{NaOH}$ solution with the required concentration was prepared by dissolving $\mathrm{NaOH}$ pellets in tap water and then leaving the solution to cool down for at least 24 hours before use. A commercially available sodium silicate solution (with $\mathrm{Na}_{2} \mathrm{O}=12.8 \%, \mathrm{SiO}_{2}=25.5 \%, \mathrm{H}_{2} \mathrm{O}=61.7 \%$ ) was used as a control activator solution, and this was supplied by Fisher Scientific UK. Tap water and natural sand (graded 0/4 mm, grain density 2.69 $\mathrm{g} / \mathrm{cm}^{3}$ ) were used for the mortar mixes.

\subsection{Paste and mortar mixes}

Activator dosage was determined according to two parameters: Alkali Dosage $(\mathrm{M}+)$ and Alkali Modulus (AM). $\mathrm{M}+$ is the mass percentage of $\mathrm{Na}_{2} \mathrm{O}$ in the activation solution to the total binder content. $\mathrm{AM}$ is the mass ratio of $\mathrm{Na}_{2} \mathrm{O}$ to $\mathrm{SiO}_{2}$ in the activation solution. $\mathrm{M}+$ and $\mathrm{AM}$ used were $7.5 \%$ and 1.0 
respectively based on previous work (Rafeet, 2016). The Water/Solid ratio (W/S) is the mass ratio of water (including free water plus water in activating solutions) over the mass of binder and added solid chemical activator $\left(\mathrm{Na}_{2} \mathrm{O}\right.$ and $\left.\mathrm{SiO}_{2}\right)$. This ratio was kept constant at 0.37 for all the samples. Mortar mix ratios are shown in Table 3, whilst mix proportions in $\mathrm{kg} / \mathrm{m}^{3}$ for RHA-derived mortars and control mortar mixes produced with commercially available activators are shown in Table 4. Samples "Control 1" were produced with $\mathrm{M}+7.5 \%$ and $\mathrm{AM}=1.0$ using commercially available sodium hydroxide solution and sodium silicate solution, whilst samples "Control 2" were produced using only $\mathrm{NaOH}$ (i.e., AM = $\infty$ ), in order to determine the lower threshold, i.e., no silicate in the mix.

Pastes were produced with the same proportions as the mortars but without sand.

Table 3 Mix ratios for mortars

\begin{tabular}{lc}
\hline Ratio & Value \\
\hline Binder composition (FA:GGBS) & $60: 40$ \\
$\mathrm{AM}=\mathrm{Na}_{2} \mathrm{O} / \mathrm{SiO}_{2}$ & 1.0 \\
$\mathrm{M}+=\mathrm{Na}_{2} \mathrm{O} / \mathrm{Binder}(\%)$ & 7.5 \\
$\mathrm{Sand} / \mathrm{Binder}$ & 2.75 \\
$\mathrm{~W} / \mathrm{S}$ & 0.37 \\
\hline
\end{tabular}

Table 4 Mix proportions for mortars

\begin{tabular}{lccc}
\hline Constituent & $\begin{array}{c}\text { RHA-derived } \\
\text { sol. }\end{array}$ & Control 1 & Control 2 \\
\hline FA $\left(\mathrm{kg} / \mathrm{m}^{3}\right)$ & 325.8 & 320.9 & 329.4 \\
GGBS $\left(\mathrm{kg} / \mathrm{m}^{3}\right)$ & 217.2 & 213.9 & 219.6 \\
Sand $\left(\mathrm{kg} / \mathrm{m}^{3}\right)$ & 1493.1 & 1470.8 & 1509.6 \\
RHA-derived solution $\left(\mathrm{kg} / \mathrm{m}^{3}\right)$ & 195.6 & - & - \\
Sodium silicate solution $\left(\mathrm{kg} / \mathrm{m}^{3}\right)$ & - & 157.3 & - \\
NaOH $30 \%$ solution $\left(\mathrm{kg} / \mathrm{m}^{3}\right)$ & 118.7 & 85.9 & 177.1 \\
Water $\left(\mathrm{kg} / \mathrm{m}^{3}\right)$ & 16.3 & 70.4 & 94.4 \\
\hline
\end{tabular}

\subsection{Mixing, casting and curing procedures}

Pastes and mortars were mixed in a planetary mixer, according to the following mixing procedure (Rafeet, 2016): (a) FA and GGBS were initially blended manually to ensure the homogeneity of the binder; (b) sand was added to the mix and this was dry mixed for one minute; (c) water, sodium hydroxide solution and sodium silicate solution were mixed together and added to the dry constituents and mixed for a further 5 minutes.

The wet mix was cast in 50x50x50 mm PVC moulds, covered by a plastic film to prevent evaporation, and then cured at room temperature. Samples were demoulded after 24 hours, labelled and then put back 
until testing into a controlled temperature curing room $\left(\mathrm{t}=20 \pm 2{ }^{\circ} \mathrm{C}\right)$ with a relative humidity (fixed by the chamber conditions) of $50 \pm 5 \%$.

\subsection{Cube compressive strength and setting time determination}

Compressive strength was tested at 1, 7 and 28 days. A first set of tests aimed at assessing the effect of different parameters involved in sodium silicate solution production on the mortar cube compressive strength. Two $50 \mathrm{~mm}$ cube specimens for each mix were crushed at each testing age for this set. A second set of tests aimed at comparing the mechanical properties of samples mixed with RHA-derived silicate solution with the mechanical properties of samples mixed with commercially available chemicals. Three $50 \mathrm{~mm}$ cube specimens for each mix at each testing age were tested in this second set of experiments. The loading rate was set at $0.6 \mathrm{~N} /\left(\mathrm{mm}^{2} \cdot \mathrm{s}\right)$ according to BS EN 12390-3:2009.

The initial and final setting time of mortar mixes were determined by probe penetration resistance according to ASTM standard C403M-08.

\subsection{Heat of hydration, chemical and microstructural investigations}

A TAM Air isothermal calorimeter (IC) was used to determine the heat of hydration of pastes activated with different solutions. $3 \pm 0.01 \mathrm{~g}$ of blended GGBS and FA powders were mixed with the required amount of alkaline activator solutions into capped glass vials and then lowered into the machine which was set at $20^{\circ} \mathrm{C}$.

Microstructural characterisation was carried out on pastes by X-ray diffraction (XRD), thermogravimetric analysis (TG/TGA) and Fourier transform infrared spectroscopy (FTIR). XRD tests were carried out using pure copper-K-Alpha 1 radiation with wavelength $1.54 \AA$. The X-ray generator was set to $40 \mathrm{kV}$ and $40 \mathrm{~mA}$, the recorded angular range was 5 to $70^{\circ}(2 \theta)$ with a step close to $0.017^{\circ}$. Samples for microstructural characterisation were obtained by hand grinding fragments from crushed paste samples in a mortar with a pestle. These were then stored in airtight plastic bags and in a glass vacuum desiccator prior to testing.

\section{RESULTS AND DISCUSSION}

Heating duration and temperature, and $\mathrm{NaOH}$ concentration were investigated as main factors affecting the silicate dissolution from RHA. The investigation also assessed the effects of the RHA-based sodium silicate solution (RHA sol.) on the setting time, mechanical strength, as well as microstructural characteristics such as the reaction products of the alkali activated paste and mortar. As mentioned in Section 2.4, these results were compared to two mortar mixes prepared with commercially available activators, "Control 1" and "Control 2", which were produced with commercially available sodium hydroxide solution and sodium silicate solution, and using only $\mathrm{NaOH}$, respectively.

\subsection{Optimum procedure for RHA -derived sodium silicate solution production}

The influence of production parameters on the dissolution of silicates was investigated with the aim of obtaining a high $\mathrm{SiO}_{2}$ content. The obtained solutions were then used to produce the mortar with mix 
proportions as shown in Table 4. It was assumed that the solution containing the highest $\mathrm{SiO}_{2}$ content would give the highest strength when used for activating the binder.

\subsubsection{Effect of $\mathrm{NaOH}$ concentration.}

The effect of the concentration of $\mathrm{NaOH}$ solution on the dissolution rate of $\mathrm{SiO}_{2}$ was investigated through the production of 5 solutions with $\mathrm{NaOH}$ concentrations varying from 1 to $6.5 \mathrm{M}$ kept stirred at $80{ }^{\circ} \mathrm{C}$ for 3 hours. The dissolution rate of $\mathrm{SiO}_{2}$ increased with the increase of the $\mathrm{NaOH}$ concentration in the solution. However, Figure 5 shows that there was no significant increase in the yield of silica when the $\mathrm{NaOH}$ concentration was higher than 2 - $3 \mathrm{M}$, which already led to $95 \%$ of silica dissolution.

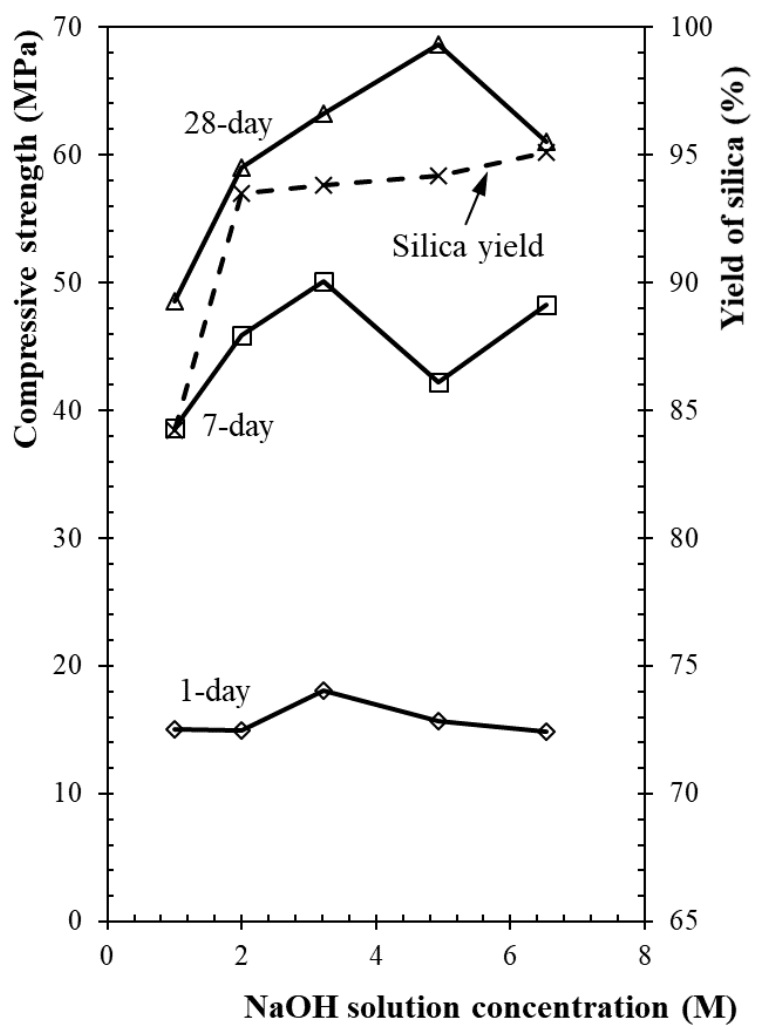

Figure 5 Effect of $\mathrm{NaOH}$ solution concentration on the yield of silica and mortar compressive strength. Yield of silica was measured on the solution and therefore is not a time-dependent factor.

Concentrations lower than $2 \mathrm{M}$ (i.e. lower $\mathrm{pH}$ of the solution) were presumably not suitable for obtaining the maximum $\mathrm{SiO}_{2}$ dissolution. The reduction of the final compressive strength of mortar samples when $\mathrm{NaOH}$ concentration was lower than $2 \mathrm{M}$ indicates that the $\mathrm{pH}$ value of these solutions may entail changes in the degree of polymerisation of the dissolved chemical species (Torres-Carrasco and Puertas, 2015).

\subsubsection{Effect of heating temperature and process duration.}

In order to investigate the effect of heating temperature and heating time on the dissolution rate of $\mathrm{SiO}_{2}$, $316 \mathrm{~g}$ of $\mathrm{NaOH}$ solution with concentration $3.0 \mathrm{M}$ and $100 \mathrm{~g}$ of RHA were stirred for 3 hours at different 
temperatures, i.e. $60,80,90$, and $100{ }^{\circ} \mathrm{C}$. The yield of silica increased with the increase of the temperature from 60 to $80{ }^{\circ} \mathrm{C}$, but no further significant increases were recorded for higher process temperatures, see Figure 6a. 7-day compressive strength for heating at $90{ }^{\circ} \mathrm{C}$ seemed not to follow the trend, but 28-day results was as expected.

The temperature of $80^{\circ} \mathrm{C}$ was then chosen in order to investigate the effect of heating duration. Both mortar cube strength and yield of silica results indicated that there was an increase in $\mathrm{SiO}_{2}$ dissolution (associated with an increase in compressive strength) from 1 to $3 \mathrm{~h}$ of heating duration, whilst the optimum seemed to be reached between 5 and 7 hours. However, the gain in $\mathrm{SiO}_{2}$ dissolution and in compressive strength for longer heating durations seemed not enough to justify a process time longer than 3 hours, see Figure $6 b$.
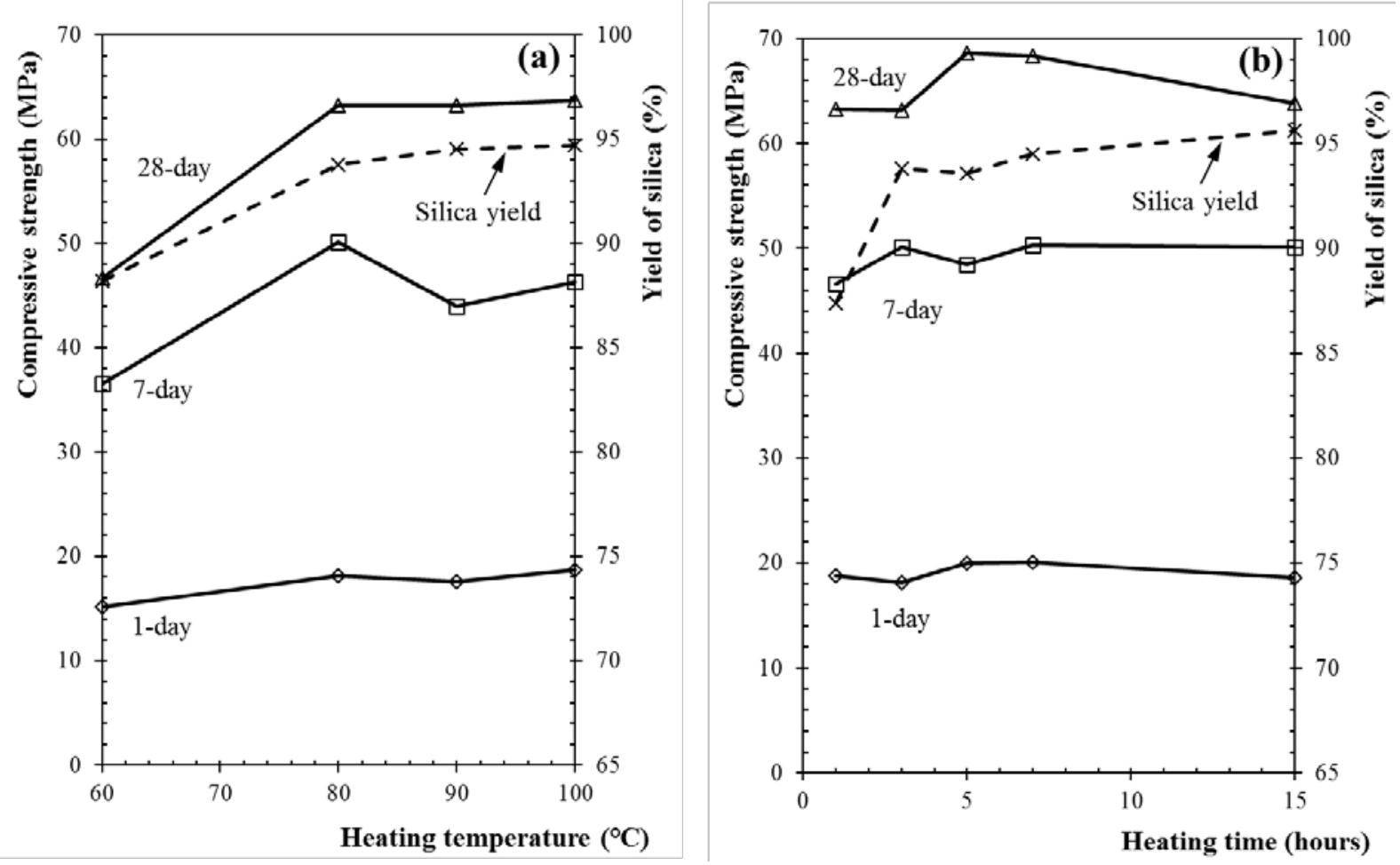

Figure 6 Effect of (a) heating temperature and (b) heating time on the yield of silica and mortar compressive strength.

Obtained results seemed to indicate that the optimal process parameters for the production of RHA derived sodium silicate solution were: concentration of $\mathrm{NaOH}$ solution of about $3 \mathrm{M}$ and heating temperature of $80^{\circ} \mathrm{C}$ for 3 hours. A marked reduction in the $\mathrm{NaOH}$ content of the dissolving solution was achieved when compared to available literature (Bouzón et al., 2014, Tchakouté et al., 2016a), with obvious positive impacts on economic and environmental performances. 


\subsection{Efficiency of RHA-derived sodium silicate solution}

The assessment of the effects of the factors involved in the production of silicate solution allowed the selection of a set of parameters leading to the best compromise. High silica yield was obtained with reasonable process duration and temperature and low amount of $\mathrm{NaOH}$ in solution.

The efficiency of the developed RHA-derived solution in activating GGBS/FA binder was assessed against the commercially available activators. Results from setting time and compressive strength of mortar prepared with the RHA-derived solution were compared with results obtained with mortars prepared with commercially available activators: "Control 1" was mixed using sodium hydroxide solution and sodium silicate solution to match the dosage $\mathrm{M}+7.5 \%$ and $\mathrm{AM}=1.0$, whilst "Control 2" was produced without sodium silicate (i.e., $\mathrm{AM}=\infty$ ). These were also used for comparing the microstructure of pastes with IC, TGA, XRD, and FTIR analysis.

\subsubsection{Setting time}

Initial and final setting times of mortars mixed with RHA-derived and commercially available chemicals are shown in Figure 7. Both initial and final setting times of the mortars with RHA-derived solution were shorter than those of the commercial solution. This seemed to indicate that the silicates in the RHAderived solution are more readily available for the reaction, confirming the high activation potential of RHA-derived sodium silicates. As expected, neat $\mathrm{NaOH}$ activation (i.e., Control 2 mix) resulted in longer setting times as no silicates were available in the solution and the reaction was therefore slower. 

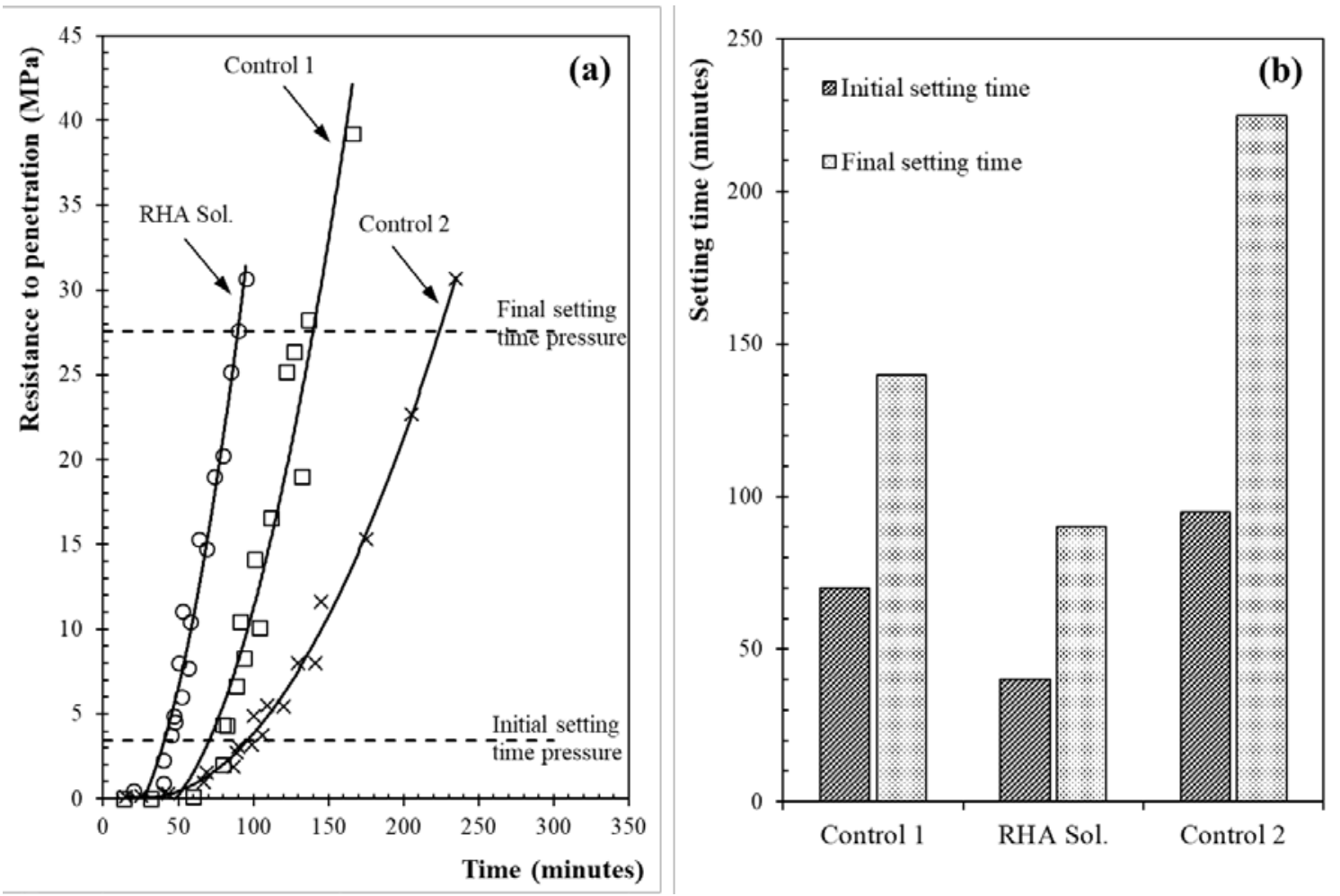

Figure 7 Setting times of mortars of mortars activated with RHA-derived and commercial alkaline solutions (a) raw data from the penetration tests. (b) interpretation and comparison with "control” mixes.

\subsubsection{Compressive strength}

The compressive strength development of mortars activated with RHA-derived waterglass, Control 1 and Control 2 mixes are shown in Figure 8.

The compressive strength values of mortar samples prepared with RHA-derived waterglass were overlapping those obtained with mortar Control 1 prepared with the commercial activators, confirming that the amount and the reactivity of dissolved silicates in the RHA-derived solution were similar to the commercial sodium silicate solution. The obtained strengths were also much higher than those of the mortar activated with $\mathrm{NaOH}$ only (i.e. Control 2, no $\mathrm{SiO}_{2}$ ). The results obtained confirmed that the activation potential of RHA-derived sodium silicate was equivalent to that of the commercially available waterglass, with the former potentially leading to lower cost and better environmental performance than the latter. Results on compressive strength are consistent with literature on metakaolin-based and slagbased AABs (Bernal et al., 2015). Previous results on fly ash/slag based AAB (Mejía et al., 2013), obtained dissolving RHA in $\mathrm{NaOH}$ solution at room temperature for $24 \mathrm{~h}$, suggested that the strength of control samples was not achieved by RHA-based solution, which is in contrast with results from this study. A possible reason can be that room temperature dissolution did not resulted in the same silicate yield as the heated process, but no information on the amount of dissolved silica was given in the paper. 


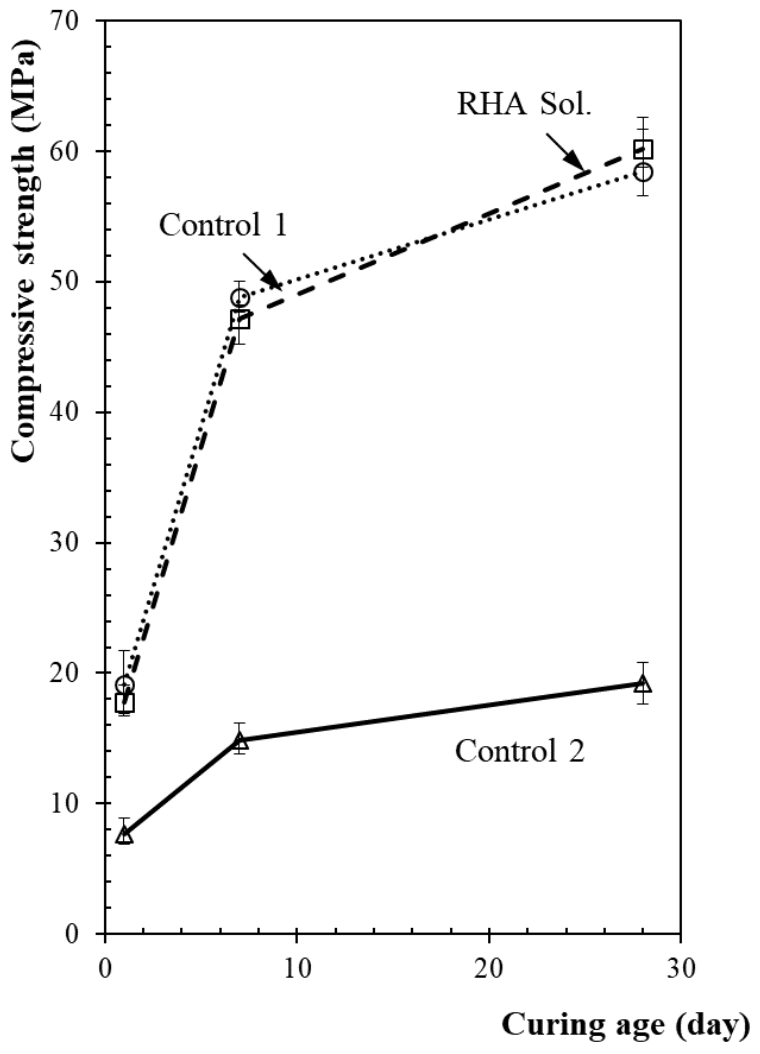

Figure 8 Compressive strength of mortars activated with RHA-derived and commercial alkaline solutions

\subsubsection{Heat of reaction - Isothermal calorimetry}

The effect of RHA-derived solution on the rate of heat evolution of the alkaline activated pastes was determined with an isothermal calorimeter set at $20{ }^{\circ} \mathrm{C}$. Figure 9a shows the heat output of the investigated pastes, where three peaks can be identified. The first one developed after about 1 hour, with a marked difference between the sample activated with $\mathrm{NaOH}$ only (Control 2) and samples activated with waterglass (Control 1). This peak is presumably due to the dissolution of $\mathrm{Si}$ and $\mathrm{Al}$ from the precursor materials. $\mathrm{NaOH}$ only activation showed a higher peak, presumably due to the higher $\mathrm{pH}$ of the pore solution, but this reduced to below $2 \mathrm{~mW} / \mathrm{g}$ very quickly, suggesting that only a partial dissolution was achieved. The second peak, developed between 80 and 90 minutes for samples prepared with waterglass, is probably due to the formation of calcium silicate hydrate gel, which is promoted by the availability of free Si species in the activating solution. The heat flows continued for a longer time and only reduced to below $2 \mathrm{~mW} / \mathrm{g}$ after 2.5 hours. This second peak was instead delayed until about 3 hours for the $\mathrm{NaOH}$ solution only. The last peak developed over a broad hump after about 15 - 16 hours and was noticeable only for the RHA-derived waterglass-based sample. RHA-derived waterglass sample seemed to show a quicker heat development than the sample prepared with the commercial activators, i.e. the first two peaks appeared earlier, and this may explain the shorter initial and final setting times 
reported above. When the cumulative heat output was plotted against time, see Figure 9b, the total heat for both samples containing silicate solutions was found to be similar with the cumulative heat output for RHA derived solution being marginally higher (about 8-10\%) than that for Control 1 . This difference may be due to the broad hump discussed above, recorded after $15-16$ hours, observed for RHA derived solution but not identified for Control 1. This hump can be due to some further dissolution of $\mathrm{SiO}_{2}$ from RHA due to the development of favourable pore solution conditions, but this hypothesis needs further investigation. Paste produced with $\mathrm{NaOH}$ solution only developed a lower total heat.
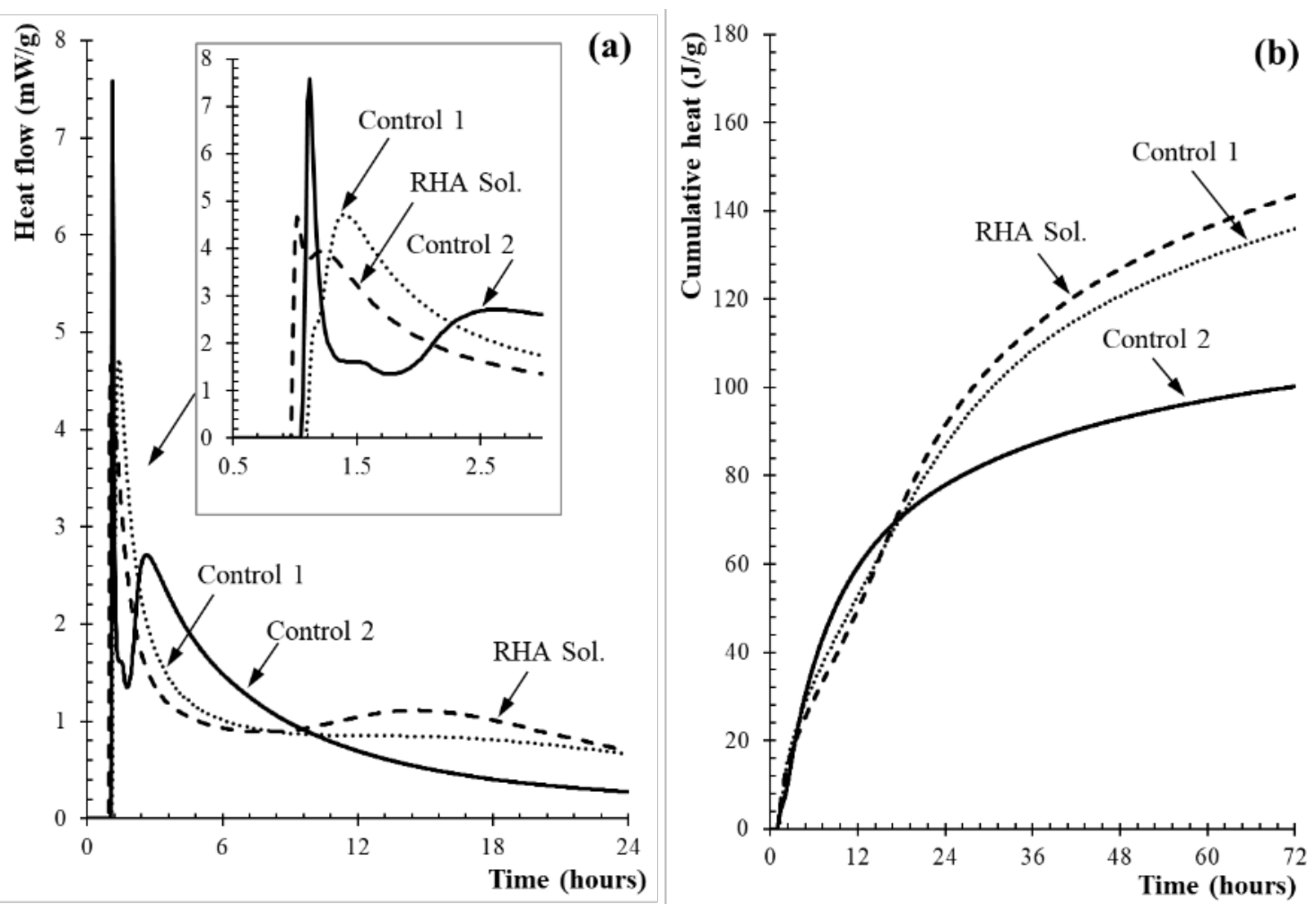

Figure 9 (a) Heat flow and (b) cumulative heat of pastes activated with RHA-derived and commercial alkaline solutions

\subsubsection{TG/DTG of GGBS/FA blends.}

Mass losses vs. heating temperature of the investigated alkaline activated paste samples are shown in Figure 10. Main mass losses occurred in the region 40 to $160{ }^{\circ} \mathrm{C}$. The physically bound water can be removed at temperatures lower than $100{ }^{\circ} \mathrm{C}$ under low heating rate conditions. The dynamic heating applied during TG test may result in free water being removed at temperatures slightly higher than 100 ${ }^{\circ} \mathrm{C}$, particularly if its presence is significant. The relatively large amount of water removed at temperatures higher than $100{ }^{\circ} \mathrm{C}$ observed in Figure 10 suggests that samples were not completely dried prior to testing. Thus, removal of physically and chemically bound water from the structure was observed. This observation is in agreement with the results of FT-IR analysis (see section 3.2.6). The mass loss calculated between 200 and $600{ }^{\circ} \mathrm{C}$ was 3.06\% and 3.25\% for samples activated with 
commercial and RHA-derived solutions respectively, whilst it was $2.22 \%$ for the sample activated with $\mathrm{NaOH}$ only. These mass losses were attributed to the progressive dehydration of chemically bound water, i.e. water bound in the calcium silicate hydrate (C-S-H) gel. Samples prepared with RHA-derived silicate solution and commercially available waterglass showed approximately the same mass loss suggesting a similar content of C-S-H gel. Paste activated with $\mathrm{NaOH}$ only showed a lower mass loss, indicating therefore a lesser amount of C-S-H gel. This observation is consistent with the higher compressive strength obtained with samples containing waterglass. Total mass losses were calculated to be in the range of $20-25 \%$ at 7 days, whilst values at 28 days were in the range $15-20 \%$. This difference was attributed to the fact that longer curing time allowed the sample to dry, as mass losses at $100{ }^{\circ} \mathrm{C}$ were lower for samples cured for 28 days, confirming that 7-day samples were not dried. Results are consistent with the literature (Tchakouté et al., 2016a, 2016b). Bernal et al. (2015) reported in their investigation on slag activated with alternative silicate solution (using silica fume and RHA) that similar amounts of reaction products were observed by TG analysis on slag binder produced with commercial and alternative activators.

(a)

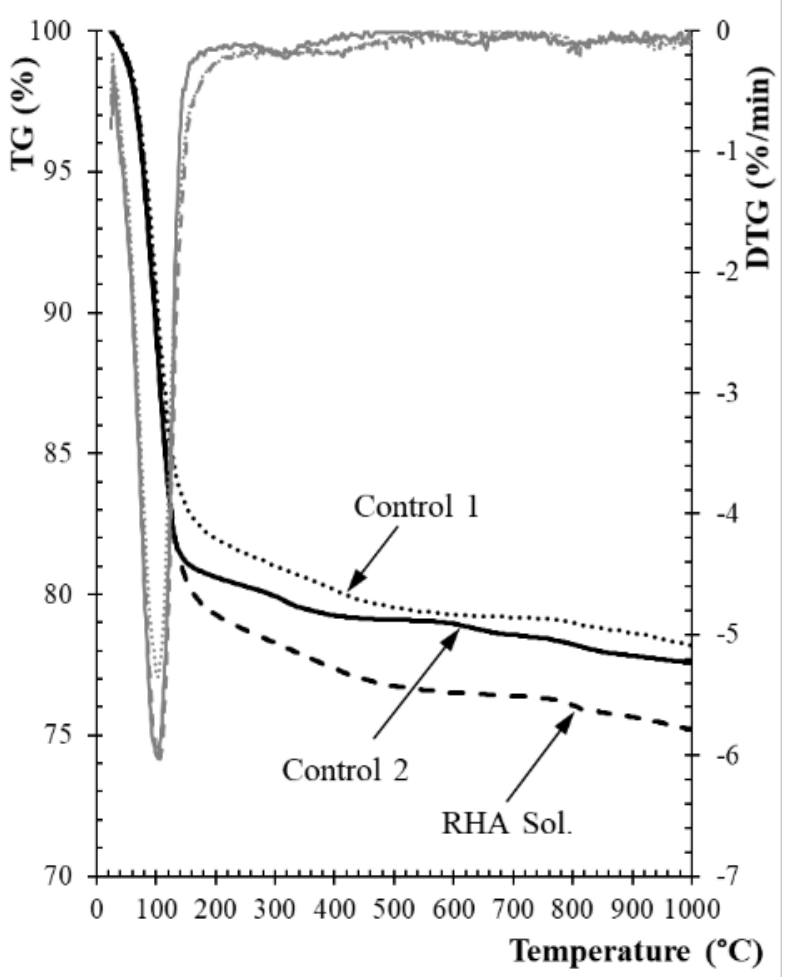

(b)

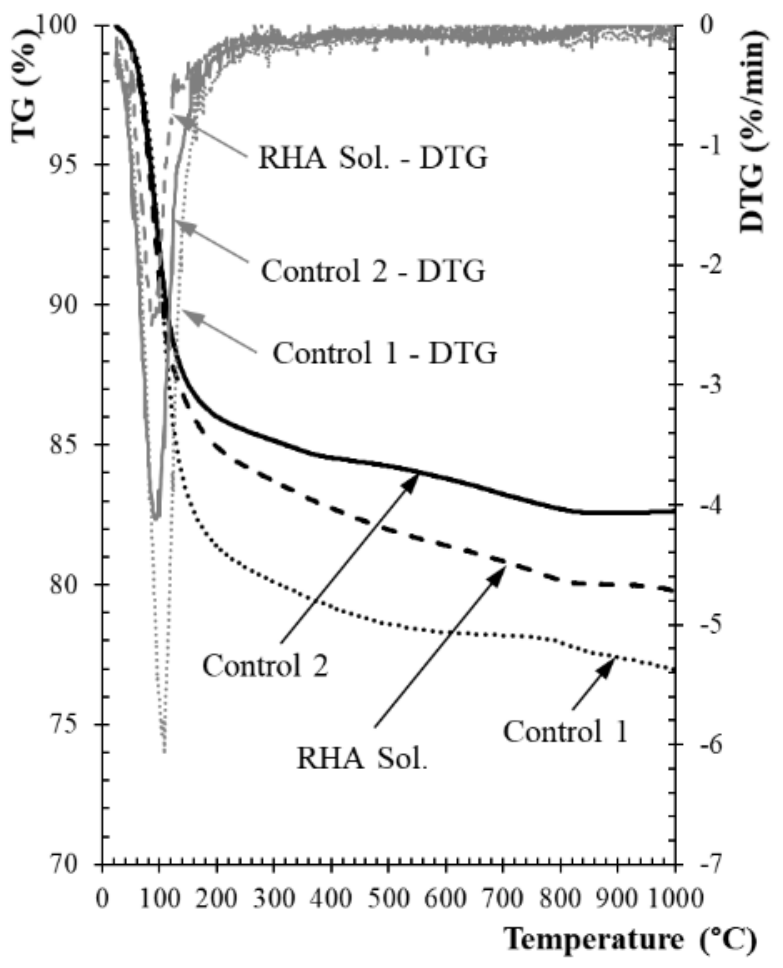

Figure 10 Thermogravimetry curves for pastes activated with RHA-derived and commercial alkaline solutions at (a) 7 days and (b) 28 days. 


\subsubsection{XRD analysis.}

The XRD patterns obtained for the three investigated samples at 7 and 28 days are shown in Figure 11. No crystalline reaction product was identified in the samples and this is due to the amorphous nature of the reaction products. The main peaks identified in all the samples were poorly ordered calcium silicate hydrate (C-S-H) type gel, quartz $\left(\mathrm{SiO}_{2}\right)$ and minor presence of mullite, these latter two resulting from fly ash. These findings are consistent with results previously reported for slag and fly ash activation in the literature (Bernal et al., 2013; Rafeet et al., 2014; Rafeet, 2016). The intensities of peaks associated with crystalline quartz and mullite in paste prepared with RHA-derived and commercial waterglass were lower than those in paste prepared with $\mathrm{NaOH}$ only (Control 2), but the intensity of C-S-H was higher, which is consistent with results from the TGA analysis. A lower intensity for crystalline phases was detected for 28-day cured samples, suggesting that the volume of C-H-S gel increased over time, which is in agreement with the increase in compressive strengths of 28-day old mortars when compared to their 7-day strength. The increase in C-S-H gel volume resulted in a dilution of the presence of quartz and mullite minerals.
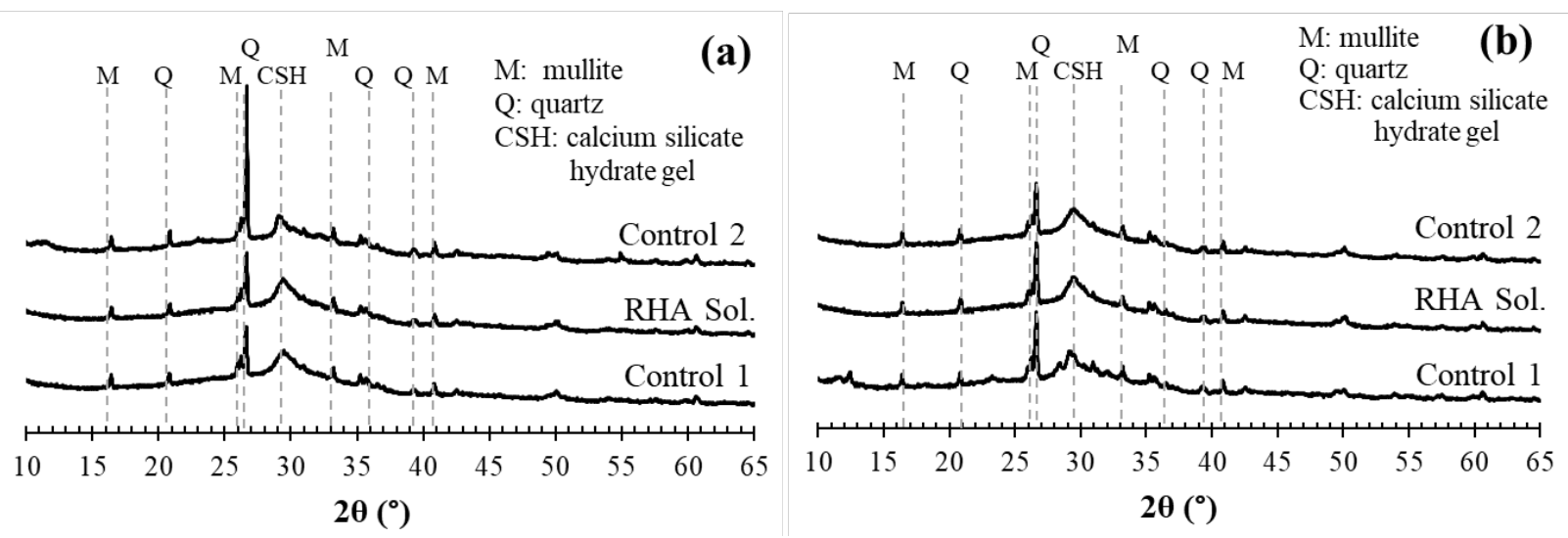

Figure 11 XRD pattern for pastes activated with RHA-derived and commercial alkaline solutions at

(a) 7 days and (b) 28 days.

\subsubsection{FT-IR analysis.}

Since XRD analysis did not allow the detection of amorphous reaction products, FTIR spectroscopy was used for investigating reacted pastes at 7 and 28 days. The band centred at $1080 \mathrm{~cm}^{-1}$ in the unreacted fly ash sample is typically assigned to the asymmetric stretching vibration of $\mathrm{X}-\mathrm{O}-\mathrm{X}$ bond ( $\mathrm{X}$ is tetrahedral Si or Al). In all tested samples (i.e. RHA-derived waterglass, Control 1 and Control 2) the X-O-X band shifted toward a lower wavenumber. The bands were centred at 948, 958 and $960 \mathrm{~cm}^{-1}$ for Control 1, RHA-derived waterglass and Control 2 pastes respectively. These shifts are attributed to the development of amorphous structures where silicate species are partially substituted by aluminate species. Figure 12 shows a hump centred at around $3400 \mathrm{~cm}^{-1}$ which is attributed to the stretching mode of $\mathrm{H}-\mathrm{OH}$ groups, whilst the peak in the wavenumber position around $1700 \mathrm{~cm}^{-1}$ is due to the bending 
vibration of $\mathrm{O}-\mathrm{H}$ of the hydrated reaction products. No significant difference was observed between samples prepared with RHA-derived silicate solution and commercially available waterglass, confirming that the reaction products are similar and thus the RHA-derived solution is suitable for alkali activation. Similar observations were reported by Bernal et al. (2012), where slight differences between samples activated with commercial chemicals and samples activated with RHA-based sodium silicate were ascribed to the presence of unreacted $\mathrm{SiO}_{2}$ in RHA. Samples at 28 days seemed to show a smaller hump in the range $3400 \mathrm{~cm}^{-1}$, which can be attributed to a lower moisture content of the material, which is in agreement with the results from TG and confirmed that samples were not completely dried when tested.

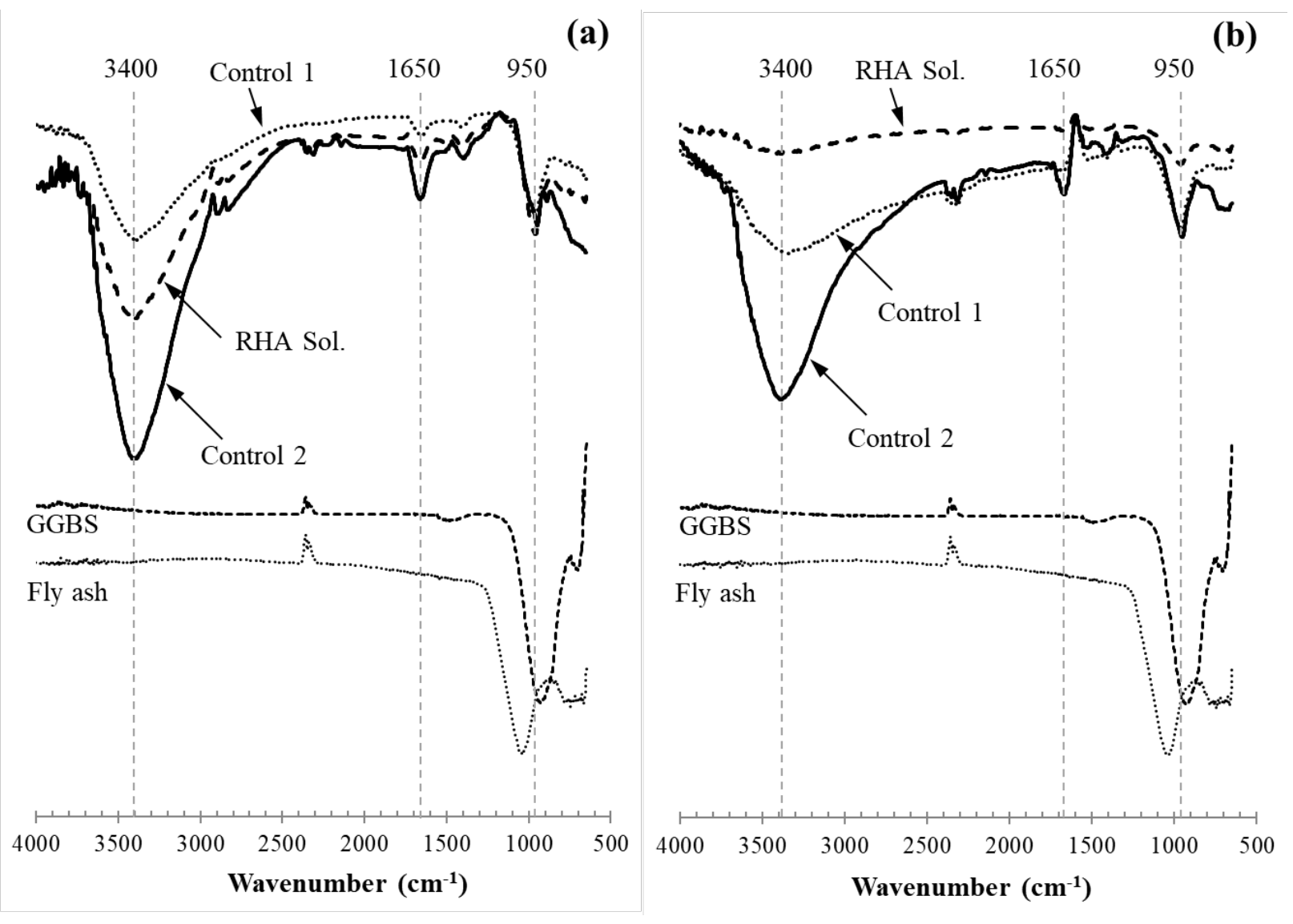

Figure 12. FTIR spectra for unreacted FA, GGBS and pastes activated with RHA-derived and commercial alkaline solutions at (a) 7 days and (b) 28 days.

\section{COST ANALYSIS}

A preliminary cost analysis was carried out in order to determine the economic benefit of using the RHA-derived waterglass instead of commercially available activators for the production of alkali activated concrete. The mix proportioning of concrete is a complex task that involves a large number of parameters and must take into account mix constituents as well as desired properties of the concrete. 
When discussing the cost analysis of concrete, some simplifications are needed. Recent research on AAC suggested a range of binder content of 300 to $400 \mathrm{~kg} / \mathrm{m}^{3}$ (Rafeet et al., 2017). An average of 350 $\mathrm{kg} / \mathrm{m}^{3}$ was considered in this analysis.

Costs associated with the production of the RHA-derived waterglass are mainly: (a) the cost of RHA, (b) the cost of $\mathrm{NaOH}$, (c) the cost of energy for heating the solution up to the process temperature (i.e., $80{ }^{\circ} \mathrm{C}$ ) over the process duration (i.e., 3 hours).

For this preliminary analysis, transportation costs were not considered, i.e., it was assumed that RHA was available locally. However, even under the scenario of using RHA procured on the industrial market, transportation costs would not be included, for two reasons: (a) realistic and accurate information on the position of a possible production plant as well as on the origin of the materials would be needed. (b) Transportation costs should also be included in the analysis of the commercial sodium silicate solution option. Transportation costs would only offset the results (considering a similar origin for the procured goods) but would not significantly affect the ratio between the two options. Furthermore, transportation costs calculated per unit of $\mathrm{SiO}_{2}$ would be higher for commercial silicate solution than for RHA, as only about $30-35 \%$ by mass of the solution is silica, whilst RHA is composed of about $90 \%$ of $\mathrm{SiO}_{2}$. Not including transportation costs was therefore considered a conservative hypothesis.

Commercial website trading amorphous RHA powder with minimum $\mathrm{SiO}_{2}$ content in the range of $90 \%$ to $95 \%$ (i.e. ash with similar properties as the RHA used in this study, without need for pre-treatments) gave price ranges from 100 to $225 £$ /t (USD 140 - 300 per tonne, FOB) for suppliers from South-East Asian region (Alibaba trading website, 2018a). A price equal to $150 £ / t$ was considered suitable for the analysis, inclusive of any required pre-treatment.

The same trading website suggested cost of $\mathrm{NaOH}$ in the range 337 to $374 £ / t$, i.e. USD $450-500$ per tonne (Alibaba trading website, 2018b), and cost for sodium silicate solution in a similar range (Alibaba trading website, 2018c). A price equal to $350 £ / t$ was adopted for the calculation for both the chemicals. The energy cost can be estimated considering a simplified model where the solution is heated from 20 ${ }^{\circ} \mathrm{C}$ to $80^{\circ} \mathrm{C}$ in an insulated vessel. At the beginning of the process, the system consists of $\mathrm{NaOH}$ solution with concentration $3 \mathrm{M}$ and dispersed particles of RHA powder, whilst at the end of the process a solution with about $22 \% \mathrm{SiO}_{2}, 7 \% \mathrm{Na}_{2} \mathrm{O}$ and $69 \% \mathrm{H}_{2} \mathrm{O}$ is obtained. The heat capacity of the initial $\mathrm{NaOH}$ solution can be assumed to be $3900 \mathrm{~J} /\left(\mathrm{kg} \cdot{ }^{\circ} \mathrm{C}\right)$, whilst the heat capacity of the final sodium silicate solution can be assumed to be $3400 \mathrm{~J} /\left(\mathrm{kg} \cdot{ }^{\circ} \mathrm{C}\right.$ ) (McCready, 1951). A conservative value of $3700 \mathrm{~J} /\left(\mathrm{kg} \cdot{ }^{\circ} \mathrm{C}\right.$ ) was assumed in the calculation. The efficiency of the insulation system in maintaining the required temperature of the vessel over the time was assumed to be $30 \%$ (i.e., some energy is required to keep the temperature for 3 hours as the insulation of the hypothetical vessel is not perfect). A further simplification in the analysis was that the heat developed by the dissolution of $\mathrm{NaOH}$ in water was not 
taken into account. The simplifications introduced were conservative, and therefore the estimation of the actual energy required was more than the actual that would be needed.

The energy required for the production of the solution can be calculated as follows:

$E=\frac{C_{p} \times m \times \Delta T}{\varepsilon}$

where $C_{p}$ is the heat capacity of the solution, $m$ is the mass of solution, $\Delta T$ is the increase in temperature (i.e., from $20^{\circ} \mathrm{C}$ to $80^{\circ} \mathrm{C}$ ), and $\varepsilon$ is the efficiency of the insulation.

The unit cost for energy was assumed to be $0.15 £ / \mathrm{kWh}$ (typical UK cost), although this is a conservative hypothesis as the cost of energy for industry in Vietnam is about $0.09 £ / \mathrm{kWh}$ for the most expensive option (peak hour, voltage of below $6 \mathrm{kV}$ customer group) as per information obtained online (EVN, 2018).

Table 5 shows the details for the calculation of the required energy, whilst Table 6 shows the details for the calculation of the cost of one tonne of RHA-based sodium silicate solution.

Table 5 Energy required for the production of 1 tonne of RHA-based sodium silicate solution

\begin{tabular}{lcc}
\hline Parameter & Units & Value \\
\hline $\mathrm{C}_{\mathrm{p}}$ & $\mathrm{J} /\left(\mathrm{kg} \cdot{ }^{\circ} \mathrm{C}\right)$ & 3700 \\
$\mathrm{~m}$ & $\mathrm{~kg}$ & 1000 \\
$\Delta \mathrm{T}$ & ${ }^{\circ} \mathrm{C}$ & 60 \\
$\varepsilon$ & - & 0.3 \\
Energy & $\mathrm{J}$ & $7.40 \mathrm{E}+8$ \\
Conversion factor & $\mathrm{kWh} / \mathrm{J}$ & $2.78 \mathrm{E}-7$ \\
\hline Energy & $\boldsymbol{k W h}$ & $\mathbf{2 0 5 . 7 2}$ \\
\hline
\end{tabular}

Table 6 Cost determination of 1 tonne of RHA-based sodium silicate solution

\begin{tabular}{lcccc}
\hline Constituent & Units & $\begin{array}{c}\text { Unit cost } \\
\text { (£/unit) }\end{array}$ & $\begin{array}{c}\text { Quantity } \\
\text { (unit/t) }\end{array}$ & $\begin{array}{c}\text { Cost } \\
\text { (£/t of solution) }\end{array}$ \\
\hline RHA & $\mathrm{t}$ & 150 & 0.240 & 36.00 \\
$\mathrm{NaOH}$ & $\mathrm{t}$ & 350 & 0.087 & 30.45 \\
Energy & $\mathrm{kWh}$ & 0.15 & 205.72 & 30.86 \\
Water & $\mathrm{t}$ & 1 & 0.673 & 0.67 \\
\hline Total cost $(\boldsymbol{£} / \mathbf{t})$ & & & & $\mathbf{9 7 . 9 8}$ \\
\hline
\end{tabular}

With the above assumptions and based on the composition of the RHA-derived solution ( $\mathrm{NaOH} \mathrm{8.7 \% ,}$ RHA $24 \%$, water $67.3 \%$, in mass), the cost of 1 tonne of solution can be estimated to be $£ 98$. 
Table 7 shows the data used for comparing the cost of the RHA-derived activation option versus commercial activation option, assuming the binder content to be $350 \mathrm{~kg} / \mathrm{m}^{3}$, water to solid ratio $=0.38$ and activation dosage of $\mathrm{M}+=7.5 \%$ and $\mathrm{AM}=1.0$.

Table 7 Cost comparison for the activation of $1 \mathrm{~m}^{3}$ of AAC

\begin{tabular}{lccccc}
\hline Constituent & $\begin{array}{c}\text { Unit } \\
\text { cost } \\
(\mathbf{E} / \mathbf{t})\end{array}$ & $\begin{array}{c}\text { RHA-based } \\
\text { option } \\
\text { quantities } \\
\left(\mathbf{k g} / \mathbf{m}^{\mathbf{3}}\right)\end{array}$ & $\begin{array}{c}\text { RHA-based } \\
\text { option cost } \\
\left(\mathbf{(} / \mathbf{m}^{3}\right)\end{array}$ & $\begin{array}{c}\text { Commercial } \\
\text { option } \\
\text { quantities } \\
\left(\mathbf{k g} / \mathbf{m}^{\mathbf{3}}\right)\end{array}$ & $\begin{array}{c}\text { Commercial } \\
\text { option cost } \\
\left(\mathbf{E} / \mathbf{m}^{3}\right)\end{array}$ \\
\hline RHA-derived solution & 98 & 120 & 11.76 & - & - \\
Sodium silicate solution & 350 & - & - & 102.9 & 36.02 \\
NaOH & 350 & 20.5 & 7.18 & 16.9 & 5.92 \\
Water & 1 & 72.2 & 0.07 & 89.5 & 0.09 \\
\hline Total activation $\operatorname{cost}\left(\mathbf{(} / \mathbf{m}^{\mathbf{3}}\right)$ & & & $\mathbf{1 9 . 0 1}$ & $\mathbf{4 2 . 0 2}$ \\
\hline
\end{tabular}

Activation with RHA-derived waterglass allows a reduction of almost $55 \%$ of the cost for the activation of AAC. Since the alkali activators represent about $40 \%$ of the cost of alkali activated concrete (Rafeet et al., 2017), the use of RHA-derived waterglass would lead to savings of about $22 \%$ on the cost per cubic metre of alkali activated concrete.

\section{SUSTAINABILITY ANALYSIS}

The assessment of the sustainability of a process requires a detailed analysis based on life cycle assessment, and which requires knowledge of a number of factors that are not readily available. This is particularly the case in the initial (i.e., laboratory development) phase of the process development as is the case discussed in this paper.

Nonetheless, a preliminary analysis of the sustainability of the process, i.e., a simplified comparison that considers environmental performances of both the proposed RHA-based waterglass and commercially available waterglass, was carried out, following the method proposed by Bontempi (2017). This method was developed with the aim of assessing the environmental sustainability of the substitution of a raw material with another material and it is based on the calculation of an index (SUB-RAW) which includes the embodied energy and $\mathrm{CO}_{2}$ footprint of selected materials (Bontempi, 2017). The method was applied considering the commercial waterglass as the "raw" material, and the RHA-derived waterglass as the "substitute” material. The SUB-RAW index was calculated as:

$S U B-R A W=\frac{\log \left(E E_{\text {raw }}\right)-\log \left(E E_{\text {sub }}\right)+\log \left(C F_{\text {raw }}\right)-\log \left(C F_{\text {sub }}\right)}{2}$ 
Where

$\mathrm{EE}_{\text {raw }}$ is the embodied energy of the raw material $(\mathrm{MJ} / \mathrm{kg})$.

$\mathrm{EE}_{\text {sub }}$ is the embodied energy of the substitute material $(\mathrm{MJ} / \mathrm{kg})$.

$\mathrm{CF}_{\text {raw }}$ is the $\mathrm{CO}_{2}$ footprint of the raw material $(\mathrm{kg} / \mathrm{kg})$.

$\mathrm{CF}_{\text {sub }}$ is the $\mathrm{CO}_{2}$ footprint of the substitute material $(\mathrm{kg} / \mathrm{kg})$.

The result of the formula is a dimensionless value between -9 and 9 . When the index is positive, the substitute material has an increased sustainability in respect with the original material, whilst the opposite applies when negative values are obtained (Bontempi, 2017).

Embodied energies and $\mathrm{CO}_{2}$ footprints were estimated for both the commercially available waterglass and for the proposed RHA-based waterglass. The values adopted in this study are to be considered indicative, as local conditions or different assumptions can have large impacts.

Embodied energy and $\mathrm{CO}_{2}$ footprint of commercially available waterglass were obtained from the literature, although with significant scatter (Jamieson et al., 2015, Fawer et al., 1999, Jyothi et al., 2017, Maskell et al., 2014, Mathew et al., 2013, Turner and Collins, 2013, Habert et al., 2011). EE raw equal to $5 \mathrm{MJ} / \mathrm{kg}$ and $\mathrm{CF}_{\text {raw }}$ equal to $1.5 \mathrm{~kg} / \mathrm{kg}$ were considered suitable values for waterglass.

Values of EE and CF for the RHA-based waterglass were estimated by consideringthe environmental impacts of rice husk combustion, production of the $\mathrm{NaOH}$ used in the solution and the solution heating process.

The combustion of rice husk involves a reaction between the available carbon and oxygen to produce $\mathrm{CO}_{2}$. Considering that (a) $240 \mathrm{~g}$ of RHA are need for $1 \mathrm{~kg}$ of solution, (b) the ash mass is about $20 \%$ of the initial rice husk mass, and (c) carbon represents about $40 \%$ of rice husk (Chungsangunsit et al., 2009), the calculation was carried out as follows:

- The mass of rice husk needed for producing the RHA required for $1 \mathrm{~kg}$ of solution was calculated to be $1.202 \mathrm{~kg}$, which corresponds to $0.481 \mathrm{~kg}$ of C, i.e. about 40 moles.

- As the reaction molar ratio C: $\mathrm{CO}_{2}$ was 1:1, the same number of moles (i.e. 40 mol.) of $\mathrm{CO}_{2}$ were assumed to be produced during the combustion.

- The $\mathrm{CO}_{2}$ emission due to the combustion of rice husk for the production of $1 \mathrm{~kg}$ of solution was therefore calculated to be $1.76 \mathrm{~kg} / \mathrm{kg}$.

- In a life cycle perspective, the biomass of rice will sequestrate the same $\mathrm{CO}_{2}$ during the cultivation season, and therefore the balance should be zero. However, in order to include other ancillary processes not currently accounted for in this simplified analysis, $10 \%$ of the calculated value (i.e., $0.176 \mathrm{~kg} / \mathrm{kg}$ ) was assumed as the contribution from the RHA preparation.

The energy obtained from the combustion of rice husk could in theory be used for production of electricity in a boiler, and indeed this would be the preferred option, provided it is technically feasible. Alternatively, the heat developed during incineration could be used for heating the solution. This would 
reduce the global energy requirement for the production of solution. However, due to the uncertainties related to this, the energy contribution from rice husk combustion was not included in the analysis. A conservative approach was adopted.

The EE of $\mathrm{NaOH}$ was assumed to be $8 \mathrm{MJ} / \mathrm{kg}$ as recommended in the literature (Jamieson et al., 2015, Fawer et al., 1999, Jyothi et al., 2017, Maskell et al., 2014, Mathew et al., 2013, Turner and Collins, 2013, Habert et al., 2011). This value was then scaled down according to the amount of $\mathrm{NaOH}$ in $1 \mathrm{~kg}$ of solution (i.e. $87 \mathrm{~g}$ ), resulting in $0.69 \mathrm{MJ} / \mathrm{kg}$. Similarly, the $\mathrm{CO}_{2}$ emission was assumed to be $1.9 \mathrm{~kg} / \mathrm{kg}$ of $\mathrm{NaOH}$, again as recommended in the literature, which was then scaled down according to the actual amount of $\mathrm{NaOH}$ in $1 \mathrm{~kg}$ of solution, and the value of $0.16 \mathrm{~kg} / \mathrm{kg}$ was used.

Under the assumptions described in section 4, the energy required for heating the solution was estimated to be $0.74 \mathrm{MJ} / \mathrm{kg}$ (i.e. $0.205 \mathrm{kWh} / \mathrm{kg}$ ). Considering a high impact scenario (i.e., electricity produced only from coal-fuelled power station, for which the conversion factor between $\mathrm{kWh}$ produced and $\mathrm{kg}$ of $\mathrm{CO}_{2}$ emitted is about 0.9 ), $\mathrm{CO}_{2}$ emission were assumed equal to $0.18 \mathrm{~kg} / \mathrm{kg}$.

All other contributions (transportation, treatments, other processing) were not included in this simplified analysis.

Table 8 shows the values adopted for the analysis and the obtained SUB-RAW index.

Table 8 Embodied energy and $\mathrm{CO}_{2}$ emission values adopted in the simplified environmental analysis

\begin{tabular}{lccc}
\hline \multicolumn{1}{c}{ Constituent } & EE (MJ/kg) & CF (kg/kg) & \\
\hline Sodium silicate solution & 5 & 1.5 & \\
RHA-derived solution & 1.43 & 0.52 & \\
Combustion of rice husk & - & 0.18 & \\
NaOH contribution & 0.69 & 0.16 & \\
Solution heating contribution & 0.74 & 0.18 & $\mathbf{0 . 4 9 9}$ \\
\hline SUB-RAW index & & & \\
\hline
\end{tabular}

The obtained SUB-RAW index was positive and therefore, for the assumptions made, it can be stated that the proposed process has an increased environmental sustainability when compared with the current industrial production of sodium silicate solution.

It is important to stress that the quality of the output from LCA analysis depends strongly on the precision of the input data. For this reason, this analysis should be considered as a preliminary assessment only, as a detailed LCA was outside the scope of this paper.

\section{CONCLUSIONS}

Alkali activated binders require a significant amount of alkali chemicals for triggering and completing their reaction, and this has repercussions on their cost and environmental footprint. The use of waste- 
derived activators can mitigate both of these problems, provided that such alternative activators show the same efficiency as commercially available chemicals.

RHA from Vietnam, obtained through an incineration process with controlled temperature and duration that produced an almost fully amorphous material, was investigated as silicate source for the production of alternative sodium silicate solution. The study focussed on a hydrothermal procedure, i.e. dissolution of RHA powder, ground to an average particle size of less than $10 \mu \mathrm{m}$, in an alkaline solution. The amorphous content of RHA is important for its dissolution in $\mathrm{NaOH}$ solution, and thus the results obtained are only representative of ash with high amorphous content.

The outcomes of the research are:

- The hydrothermal process was optimised in terms of $\mathrm{NaOH}$ concentration of the solution, process temperature and duration. $\mathrm{NaOH}$ concentration $3 \mathrm{M}$, heating temperature $80{ }^{\circ} \mathrm{C}$ and heating duration 3 allowed a $\mathrm{SiO}_{2}$ dissolution rate higher than $95 \%$. This set of parameters was the best compromise, delivering high silica yield with reasonable process duration, temperature and $\mathrm{NaOH}$ concentration.

- The RHA-derived sodium silicate solution was used for the activation of a blend of $60 \%$ fly ash and 40\% GGBS, in place of commercial sodium silicate. Compressive strength and setting time results confirmed that the obtained solution was as effective as the commercial option.

- Microstructural analysis (IC, TGA, XRD, FTIR) confirmed that the hydrothermal process was able to produce a silicate solution with the required amount of silicates in a reactive form. Pastes produced with RHA-derived solution gave similar results of those produced with commercially available waterglass, whilst paste produced with $\mathrm{NaOH}$ showed distinct differences.

- A 55\% reduction of the cost for the activation of AAC can be achieved using the RHA-derived sodium silicate solution. This would lead to about $22 \%$ cost reduction per cubic metre of AAC when compared to concrete produced with commercially available chemical activators, thus enabling its commercialisation.

- A simplified environmental analysis indicated that the proposed process has an increased environmental sustainability when compared with the current industrial production of sodium silicate solution.

\section{ACKNOWLEDGEMENTS}

This research is funded by National University of Civil Engineering (NUCE) under grant number 1082018/KHXD-TĐ. The authors also gratefully acknowledge the financial support provided by the National Foundation for Science and Technology Development- Vietnam (NAFOSTED); Queen's University Belfast and the National University of Civil Engineering for sponsoring Dr Kien Tong's partnership study programme. The Authors would also like to thank Dr Le Trung Thanh and Dr Bui Danh Dai for their guidance and valuable discussions; Dr Mark Russell for his assistance in the 
characterisation of both raw materials and reacted samples. The Authors are also grateful to Angkor Bio Cogen Co. Ltd., Cambodia, for their useful information on burning technologies available and information on power plants currently using rice hulls.

\section{REFERENCES}

Alibaba trading website, 2018a. Amorphous rice husk ash search. https://www.alibaba.com/trade/search?fsb=y\&IndexArea=product en\&CatId=\&SearchText=amo rphous+rice+husk+ash+\&isGalleryList $=\mathrm{G}$ (accessed 10 June 2018).

Alibaba trading website, 2018b. $\mathrm{NaOH} 99 \%$ pearls search. https://www.alibaba.com/trade/search?fsb=y\&IndexArea=product_en\&CatId=\&SearchText=nao $\underline{\mathrm{h}+99 \% 25+\text { pearls\&viewtype }=\mathrm{G}}$ (accessed 10 June 2018).

Alibaba trading website, 2018c. Sodium silicate solution search. https://www.alibaba.com/trade/search?f0=y\&IndexArea=product en\&CatId=\&SearchText=sodiu $\underline{\mathrm{m}+\text { silicate}+ \text { solution\&viewtype }=\text { G\&refine attr_value }=100002036-100006196}$ (accessed 10 June 2018).

Ananthi, A., Geetha, D. and Ramesh, P.S., 2016. Preparation and Characterization of Silica Material from Rice Husk Ash - An Economically Viable Method. Chemistry and Materials Research, 8(6).

Bernal, S.A., Provis, J.L., Walkley, B., San Nicolas, R., Gehman, J.D., Brice, D.G., Kilcullen, A.R., Duxson, P. and van Deventer, J.S., 2013. Gel nanostructure in alkali-activated binders based on slag and fly ash, and effects of accelerated carbonation. Cement and Concrete Research, 53, pp.127-144.

Bernal, S.A., Rodríguez, E.D., de Gutiérrez, R.M., Provis, J.L. and Delvasto, S., 2012. Activation of metakaolin/slag blends using alkaline solutions based on chemically modified silica fume and rice husk ash. Waste and Biomass Valorization, 3(1), pp.99-108.

Bernal, S.A., Rodríguez, E.D., De Gutiérrez, R.M. and Provis, J.L., 2015. Performance at high temperature of alkali-activated slag pastes produced with silica fume and rice husk ash based activators. Materiales de Construcción, 65(318), p.049.

Bhattacharyya, S.C., 2014. Viability of off-grid electricity supply using rice husk: A case study from South Asia. Biomass and bioenergy, 68, pp.44-54.

Bontempi, E., 2017. A new approach for evaluating the sustainability of raw materials substitution based on embodied energy and the $\mathrm{CO}_{2}$ footprint. Journal of Cleaner Production, 162, pp.162-169.

Bouzón, N., Payá, J., Borrachero, M.V., Soriano, L., Tashima, M.M. and Monzó, J., 2014. Refluxed rice husk ash/NaOH suspension for preparing alkali activated binders. Materials letters, 115, pp.72-74.

Bui, D., 2001. Rice husk ash as a mineral admixture for high performance concrete, Technische Univ. Delft, Netherlands, p.138. 
Chandrasekhar, S.A.T.H.Y., Satyanarayana, K.G., Pramada, P.N., Raghavan, P. and Gupta, T.N., 2003. Review processing, properties and applications of reactive silica from rice husk-an overview. Journal of materials science, 38(15), pp.3159-3168.

Chungsangunsit, T., Gheewala, S.H. and Patumsawad, S., 2009. Emission assessment of rice husk combustion for power production. World Academy of Science: Engineering and Technology, 53, p.1070.

Cui, S., Yu, S.W., Lin, B.L., Shen, X.D. and Gu, D., 2015. Preparation of $\mathrm{SiO}_{2}$ aerogel from rice husk ash. RSC Advances, 5(81), pp.65818-65826.

Davidovits, J., 1994. Global warming impact on the cement and aggregates industries. World Resource Review, 6(2), pp.263-278.

Davidovits, J., 2002, October. Environmentally driven geopolymer cement applications. In Proceedings of 2002 Geopolymer Conference. Melbourne. Australia.

Davidovits, J., 2011. Geopolymer Chemistry and Application (Institute Geopolymere, France).

Detphan, S. and Chindaprasirt, P., 2009. Preparation of fly ash and rice husk ash geopolymer. International Journal of Minerals, Metallurgy and Materials, 16(6), pp.720-726.

Duxson, P., Fernández-Jiménez, A., Provis, J.L., Lukey, G.C., Palomo, A. and van Deventer, J.S., 2007. Geopolymer technology: the current state of the art. Journal of materials science, 42(9), pp.29172933.

EVN Vietnam Electricity website, 2018. Available: https://en.evn.com.vn/d6/news/WHOLESALEELECTRICITY-TARIFF-9-28-260.aspx (Accessed 22/05/2018).

FAOSTAT, 2018. Available: http://www.fao.org/faostat/en/\#data/QC (Accessed 29 May. 2018).

Fawer, M., Concannon, M. and Rieber, W., 1999. Life cycle inventories for the production of sodium silicates. The International Journal of Life Cycle Assessment, 4(4), p.207.

Fernandes, I.J., Calheiro, D., Sánchez, F.A., Camacho, A.L.D., Rocha, T.L.A.D.C., Moraes, C.A.M. and Sousa, V.C.D., 2017. Characterization of Silica Produced from Rice Husk Ash: Comparison of Purification and Processing Methods. Materials Research, (AHEAD), pp.0-0.

Foletto, E.L., Gratieri, E., Oliveira, L.H.D. and Jahn, S.L., 2006. Conversion of rice hull ash into soluble sodium silicate. Materials Research, 9(3), pp.335-338.

Geraldo, R.H., Fernandes, L.F. and Camarini, G., 2017. Water treatment sludge and rice husk ash to sustainable geopolymer production. Journal of cleaner production, 149, pp.146-155.

Ghosh, R. and Bhattacherjee, S., 2013. A review study on precipitated silica and activated carbon from rice husk. J Chem Eng Process Technol, 4(4), pp.1-7.

Habert, G., De Lacaillerie, J.D.E. and Roussel, N., 2011. An environmental evaluation of geopolymer based concrete production: reviewing current research trends. Journal of cleaner production, 19(11), pp.1229-1238. 
He, J., Jie, Y., Zhang, J., Yu, Y. and Zhang, G., 2013. Synthesis and characterization of red mud and rice husk ash-based geopolymer composites. Cement and Concrete Composites, 37, pp.108-118.

Hwang, C.L. and Huynh, T.P., 2015. Effect of alkali-activator and rice husk ash content on strength development of fly ash and residual rice husk ash-based geopolymers. Construction and Building Materials, 101, pp.1-9.

Jamieson, E., McLellan, B., Van Riessen, A. and Nikraz, H., 2015. Comparison of embodied energies of Ordinary Portland Cement with Bayer-derived geopolymer products. Journal of Cleaner Production, 99, pp.112-118.

Jiang, M., Chen, X., Rajabipour, F. and Hendrickson, C.T., 2014. Comparative life cycle assessment of conventional, glass powder, and alkali-activated slag concrete and mortar. Journal of Infrastructure Systems, 20(4), p.4014-4020.

Jyothi, T.K., Varsha, B.N., Raghunath, S. and Jagadish, K.S., 2017. Embodied Energy \& Cost Issues of Tank-Bed-Lime Based Geopolymer Adobes. Open Journal of Energy Efficiency, 6(03), p.128.

Kamseu, E., à Moungam, L.B., Cannio, M., Billong, N., Chaysuwan, D., Melo, U.C. and Leonelli, C., 2017. Substitution of sodium silicate with rice husk ash-NaOH solution in metakaolin based geopolymer cement concerning reduction in global warming. Journal of cleaner production, 142, pp.3050-3060.

Kapur, T., Kandpal, T.C. and Garg, H.P., 1996. Electricity generation from rice husk in Indian rice mills: potential and financial viability. Biomass and Bioenergy, 10(5-6), pp.393-403.

Karim, M.R., Zain, M.F.M., Jamil, M. and Lai, F.C., 2013. Fabrication of a non-cement binder using slag, palm oil fuel ash and rice husk ash with sodium hydroxide. Construction and Building Materials, 49, pp.894-902.

Karim, M.R., Zain, M.F.M., Jamil, M. and Lai, F.C., 2015. Development of a zero-cement binder using slag, fly ash, and rice husk ash with chemical activator. Advances in Materials Science and Engineering, 2015.

Kumar, S., Sangwan, P., Dhankhar, R.M.V. and Bidra, S., 2013. Utilization of rice husk and their ash: A review. Res. J. Chem. Env. Sci, 1(5), pp.126-129.

Liu, X., Li, Z., Chen, H., Yang, L., Tian, Y. and Wang, Z., 2016. Rice husk ash as a renewable source for synthesis of sodium metasilicate crystal and its characterization. Research on Chemical Intermediates, 42(4), pp.3887-3903.

Ma, X., Zhou, B., Gao, W., Qu, Y., Wang, L., Wang, Z. and Zhu, Y., 2012. A recyclable method for production of pure silica from rice hull ash. Powder technology, 217, pp.497-501.

Mathew, M.B.J., Sudhakar, M.M. and Natarajan, D.C., 2013. Strength, economic and sustainability characteristics of coal ash-GGBS based geopolymer concrete. International Journal of Computational Engineering Research, 3(1), pp.207-212. 
Maskell, D., Heath, A. and Walker, P., 2014. Comparing the environmental impact of stabilisers for unfired earth construction. In Key Engineering Materials (Vol. 600, pp. 132-143). Trans Tech Publications.

McCready, N.W., 1951. Specific Heats of Sodium Silicate Solutions. Industrial \& Engineering Chemistry, 43(5), pp.1154-1159.

Mehta, P.K., 2002. Greening of the concrete industry for sustainable development. Concrete international, 24(7), pp.23-28.

Mejía, J.M., de Gutiérrez, R.M. and Puertas, F., 2013. Rice husk ash as a source of silica in alkaliactivated fly ash and granulated blast furnace slag systems. Materiales de Construcción, 63(311), pp.361-375.

Mejía, J.M., de Gutiérrez, R.M. and Montes, C., 2016. Rice husk ash and spent diatomaceous earth as a source of silica to fabricate a geopolymeric binary binder. Journal of Cleaner Production, 118, pp.133-139.

Natarajan, E., Nordin, A. and Rao, A.N., 1998. Overview of combustion and gasification of rice husk in fluidized bed reactors. Biomass and bioenergy, 14(5-6), pp.533-546.

Nimwinya, E., Arjharn, W., Horpibulsuk, S., Phoo-Ngernkham, T. and Poowancum, A., 2016. A sustainable calcined water treatment sludge and rice husk ash geopolymer. Journal of cleaner production, 119, pp.128-134.

Olivier, J.G.J., Janssens-Maenhout, G., Muntean, M. and Peters, J.A.H.W., 2015. Trends in global CO2 emissions: 2015 Report. PBL Netherlands Environmental Assessment Agency, The Hague; European Commission, Joint Research Centre (JRC). Institute for Environment and Sustainability (IES).

Pal, S. C., Mukherjee, A., \& Pathak, S. R. (2003). Investigation of hydraulic activity of ground granulated blast furnace slag in concrete. Cement and Concrete Research, 33(9), 1481-1486.

Palomo, A., Grutzeck, M.W. and Blanco, M.T., 1999. Alkali-activated fly ashes: a cement for the future. Cement and concrete research, 29(8), pp.1323-1329.

Passuello, A., Rodríguez, E.D., Hirt, E., Longhi, M., Bernal, S.A., Provis, J.L. and Kirchheim, A.P., 2017. Evaluation of the potential improvement in the environmental footprint of geopolymers using waste-derived activators. Journal of Cleaner Production, 166, pp.680-689.

Provis, J.L., 2014. Green concrete or red herring?-future of alkali-activated materials. Advances in Applied Ceramics, 113(8), pp.472-477.

Rafeet, A.M.I., 2016. Mix design, fresh and hardened properties and microstructural characterisation of alkali-activated concrete based on PFA/GGBS blends (Doctoral dissertation, Queen's University Belfast). 
Rafeet, A., Vinai, R., Sha, W. and Soutsos, M., 2014, September. Alkali activated fuel ash and slag mixes: optimization study from paste to concrete building blocks. In 34th Cement and Concrete Science Conference, Paper (No. 179).

Rafeet, A., Vinai, R., Soutsos, M. and Sha, W., 2017. Guidelines for mix proportioning of fly ash/GGBS based alkali activated concretes. Construction and Building Materials, 147, pp.130-142.

Roy, D.M., 1999. Alkali-activated cements opportunities and challenges. Cement and Concrete Research, 29(2), pp.249-254.

Schneider, M., Romer, M., Tschudin, M. and Bolio, H., 2011. Sustainable cement production—present and future. Cement and Concrete Research, 41(7), pp.642-650.

Shi, C., Roy, D. and Krivenko, P., 2006. Alkali-activated cements and concretes. CRC press.

Sjahrul, M, Hasmiah, S., Zakir, M., Maming, M., 2013. Use of sodium silicate from rice husk ash basic materials for coating electrolytes in the synthesis of magnetite nanoparticles. Research Journal of Science \& IT Management 3, pp.46-56.

Soutsos, M.N., Vinai, R. and Rafeet, A., 2015. Effect of alkali dosage and modulus on strength development and microstructure of alkali-activated binders. In 14th International Congress on the Chemistry of Cement.

Soutsos, M., Boyle, A.P., Vinai, R., Hadjierakleous, A. and Barnett, S.J., 2016. Factors influencing the compressive strength of fly ash based geopolymers. Construction and Building Materials, 110, pp.355-368.

Sugita, S., 1994. Method of producing active rice husk ash. U.S. Patent 5,329,867.

Suksiripattanapong, C., Kua, T.A., Arulrajah, A., Maghool, F. and Horpibulsuk, S., 2017. Strength and microstructure properties of spent coffee grounds stabilized with rice husk ash and slag geopolymers. Construction and Building Materials, 146, pp.312-320.

Tchakouté, H.K., Rüscher, C.H., Kong, S., Kamseu, E. and Leonelli, C., 2016a. Geopolymer binders from metakaolin using sodium waterglass from waste glass and rice husk ash as alternative activators: A comparative study. Construction and Building Materials, 114, pp.276-289.

Tchakouté, H.K., Rüscher, C.H., Kong, S. and Ranjbar, N., 2016b. Synthesis of sodium waterglass from white rice husk ash as an activator to produce metakaolin-based geopolymer cements. Journal of Building Engineering, 6, pp.252-261.

Torres-Carrasco, M. and Puertas, F., 2015. Waste glass in the geopolymer preparation. Mechanical and microstructural characterisation. Journal of cleaner production, 90, pp.397-408.

Torres-Carrasco, M., Rodríguez-Puertas, C., del Mar Alonso, M. and Puertas, F., 2015. Alkali activated slag cements using waste glass as alternative activators. Rheological behaviour. Boletín de la Sociedad Española de Cerámica y Vidrio, 54(2), pp.45-57. 
Turner, L.K. and Collins, F.G., 2013. Carbon dioxide equivalent (CO2-e) emissions: A comparison between geopolymer and OPC cement concrete. Construction and Building Materials, 43, pp.125130.

Van, V.T.A., 2013. Characteristics of rice husk ash and application in Ultra-High Performance Concrete. $\mathrm{PhD}$, Bauhaus-Universität Weimar.

Van, V., Rößler, C., Bui, D.D. and Ludwig, H.M., 2013. Mesoporous structure and pozzolanic reactivity of rice husk ash in cementitious system. Construction and Building Materials, 43, pp.208-216.

Ziegler, D., Formia, A., Tulliani, J.M. and Palmero, P., 2016. Environmentally-friendly dense and porous geopolymers using fly ash and rice husk ash as raw materials. Materials, 9(6), p.466. 